\title{
Spot electoral: estrategia de visualización de candidatos en las campañas politicas
}

\section{The electoral spot: candidate visualization strategy in political campaigns}

\author{
Mario Alexander Lozano Garcia iD
}

Universidad de Boyacá, Colombia

marioalexanderlozano@gmail.com

\begin{abstract}
Hoy, en plena era de la comunicación, el político que no aparezca en televisión es como si no existiera. Por eso, para los politicos es fundamental "ser parte de lo que la gente quiere ver en pantalla, casi como un "spot"
\end{abstract}

Carceller

\begin{abstract}
Resumen
El spot electoral es descrito como "formato comunicacional comprimido, el principal espacio de comunicación audiovisual entre el electorado y los partidos políticos”, según Julio Juárez Gámiz. Este formato posee técnicas persuasivas de mercadeo politico que buscan generar cierta capacidad de influencia (negativa o positiva) sobre el electorado. La pieza publicitaria también ha sido definida por estudiosos de la comunicación política como videopolítica.

El presente artículo muestra el uso del spot en las campañas electorales de algunos candidatos a la presidencia en Colombia durante los años noventa e inicios del nuevo milenio, de aspirantes al Congreso colombiano en 2014, especialmente en el departamento de Boyacá y del proceso electivo al Congreso de la República 2018. Alli los aspirantes por Boyacá consolidan el uso de las Tecnologías de la Información y Comunicación-TIC para lograr la visualización de sus spots. Algunos elementos teóricos desarrollados obedecen a los términos ecosistema mediático electoral; las historias que logran ser contadas en los videos, basadas en siete códigos comunicativos: lenguaje lingüístico; lenguaje kinésico; lenguaje proxémico; lenguaje iridológico; lenguaje fisiológico; moda; y valores no verbales voz. El trabajo es producto del proyecto finalizado Comportamiento electoral en Boyacá 2018: desde las contiendas Congreso de la República y Presidencial.
\end{abstract}

Palabras clave: Spot político, elecciones en Colombia, departamento de Boyacá, campaña política.

\begin{abstract}
They describe the electoral spot as a "compressed communication format, the main audiovisual communication space between the electorate and political parties", it is loaded with persuasive political marketing techniques that seeks to generate a certain capacity for influence (negative or positive) on the electorate. The advertising piece has also been defined by scholars of political communication as video politics.

This article shows the use of the spot in the electoral campaigns of some candidates to the presidency in Colombia during the nineties and the beginning of the new millennium, of candidates to the Colombian Congress in 2014, especially in the department of Boyacá and the election process to the Congress of the Republic 2018. There, the candidates for Boyacá consolidate the use of Information and Communication Technologies-ICT to achieve the visualization of their spots. Some theoretical elements developed obey the terms electoral media ecosystem; the stories that manage to be told in the videos, based on seven communicative codes: linguistic language; kinesic language; proxemic language; iridological language; physiological language; fashion; and non-verbal values voice. The work is a product of the finalized project Electoral behavior in Boyacá 2018: from the Congress of the Republic and Presidential contests.
\end{abstract}

Keywords: Political spot, elections in Colombia, Boyacá department, politic campaign.

Artículo: Recibido el 20 de abril de 2021 y aprobado el 18 de mayo de 2021 


\section{Cómo citar este artículo:}

Lozano García, M (2021). Spot electoral: estrategia de visualización de candidatos en las campañas politicas. Reflexión política 23(47), pp. 98-115. doi: https://doi.org/10.29375/01240781.4137

\section{Introducción}

Antes de hablar del spot electoral, es necesario desarrollar brevemente el significado del spot publicitario, que desde el campo epistemológico se expone como "un todo comunicativo compuesto por diferentes módulos que interactúan a un mismo nivel para transmitir el mensaje, la descomposición de elementos verbales, no verbales, recursos retóricos y pragmáticos”. A su vez, una definición más operativa lo presenta como un "anuncio publicitario para ser transmitido por televisión" (Martí y Vallhonrat, 1999, p. 225; Pérez, 2010, p. 242). Esta última apreciación lleva a acotar el concepto del spot electoral, principal objeto de análisis y debate de este artículo, entendido como estrategia de visualización de candidatos con el propósito de captar votos en los debates de elección popular. Por su parte, Julio Juárez Gámiz lo describe asî: "formato comunicacional comprimido, como el principal espacio de comunicación audiovisual entre el electorado y los partidos políticos" (2010, p. 45). Este formato posee técnicas persuasivas de mercadeo político que buscan generar cierta capacidad de influencia (negativa o positiva) sobre el electorado.

La pieza publicitaria también ha sido definida por estudiosos de la comunicación política como la videopolítica. Para Deborah Fischer (2005) la videopolítica es la manera de hacer política mediatizada, principalmente por la imagen televisiva, en donde las empresas de publicidad dirigen las agendas de muchos temas ciudadanos y de gobierno, creando imágenes atrayentes que venden a los electores como publicidad (p. 133). De igual forma, Carmen Julia Carceller sostiene que la videopolítica conjuga dos aspectos populares y masivos de la vida del hombre: por un lado, la televisión (vídeo, del latín videre, que significa “ver"); por otro, la política (2013, p. 3).

Desde cualquier definición, el spot se ha convertido en pieza comunicativa vital para cualquier actor político que disputa algún proceso electoral; es decir, los competidores a cargos de elección popular se valen de distintas estrategias de persuasión para intentar ganar adeptos por medio del spot. Entre las estrategias que utilizan están el manejo discursivo, la utilización de efectos especiales, la sonorización, el desarrollo de planos, el manejo de contextos e incluso los modos de asumir la propia expresión corporal del aspirante. Todo lo anterior se comprime en treinta segundos, tras lo cual los mensajes hacen su aparición para guiar y atraer a votantes cautivos o desprevenidos y estos son absorbidos por las diferentes habilidades que despliega la comunicación política.

Todo ello refleja las diversas líneas técnicas y argumentativas existentes para abordar el fenómeno de los spots electorales en el presente trabajo como herramienta política de persuasión de votantes en los diversos debates de elección popular. Además esta herramienta comunicativa ¿no solo funciona? entre partidos políticos y posibles electores, sino también en sentido contrario: los mismos simpatizantes abanderan propuestas a favor o en contra de candidatos, mediante el empleo de tales canales comunicativos.

El origen del spot electoral se remonta a los Estados Unidos durante la campaña presidencial de 1952, que enfrentó al General Dwight David Eisenhower, del Partido Republicano, con Adlai Stevenson, candidato del Partido Demócrata (Peña, 2011). El candidato republicano, quien resultó vencedor de las contiendas, le apostó a la pieza publicitaria (spot) titulada Eisenhower responde a América. Con esta pieza logró posicionar un mensaje televisivo donde lamentó la deuda federal, los altos impuestos, y la implicación de los Estados Unidos en la guerra internacional (ver Figura 1). Según Giovanni Martínez Castillo (2010) estas líneas de combate electoral y obviamente publicitarias fueron decisivas para desarrollar un mensaje que se "conectó con los votantes; y entregar ese mensaje justo en el momento y lugar donde estaban los votantes”(p. 9).

Asimismo, la estrategia visual fue exitosa debido a la creatividad del publicista Rosser Reeves, quien colocó pequeños anuncios electorales entre los programas más populares, con lo cual alcanzó a su 
audiencia por una fracción del coste que suponían los discursos de treinta minutos. Además, al ser breves, fueron más eficaces y más memorables entre los televidentes (Peytibi, 2016, p. 150). Esto demuestra las primeras técnicas de apropiación de los spots después de la Segunda Guerra Mundial, conflicto bélico que sirvió de discurso 'inspirador' central para desarrollar historias como la caída del régimen nazi de Adolf Hitler, las bombas atómicas desplegadas en Hiroshima y Nagasaki, el Holocausto judío, y la deuda interna que dejó la confrontación en los Estados Unidos. Todos estos momentos fueron aprovechados en ítems o framing (encuadres) políticos expuestos por el equipo de creadores de Reeves.

Figura 1. Eisenhower responde a América

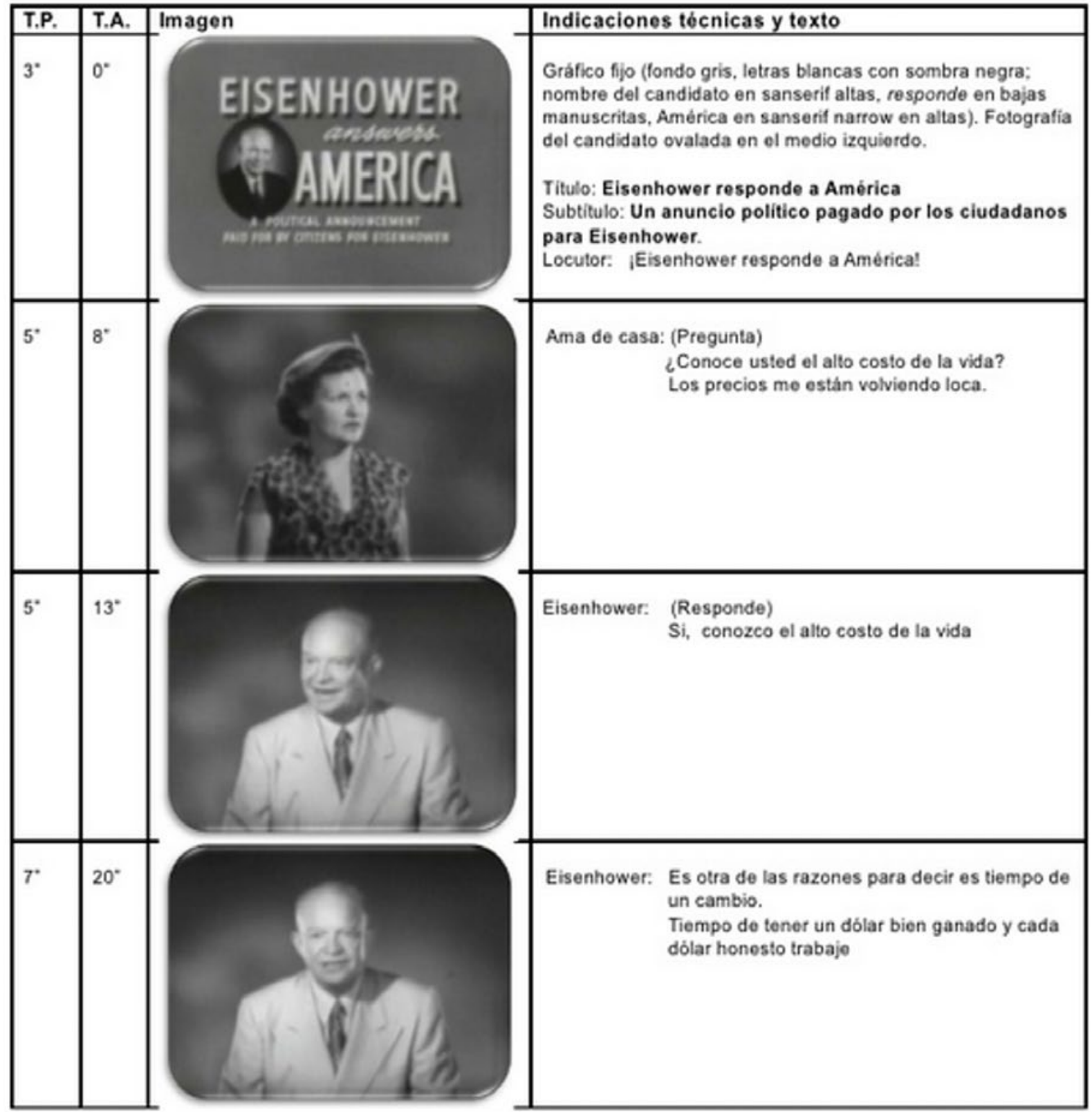

Video cortesia de la Libreria Presidencial Dwight D. Eisenhower Comparado con los datos del American Museum of the Moving Image: The Living Room Candidate

Recuperado de "Campañas presidenciales históricas de Norteamérica: (de 1952 a 2008).

La americanización de las campañas electorales”, Martínez, G., (2010, p. 10) 
De este modo, el desarrollo tecnológico de los sistemas comunicativos ha permitido paralelamente la transformación de los spots electorales, convertidos en piezas publicitarias más atractivas, con varios elementos narrativos en un solo fragmento, emitidos en directo, reproducidos en diversos formatos, y construidos por los mismos candidatos o equipos de campaña. Precisamente el auge de las plataformas relacionadas con las Tecnologías de la Información y la ComunicaciónTIC, esencialmente la conexión que vienen teniendo las redes sociales digitales (Facebook, Twitter, My Space, etcétera) hacen que los spots sean fáciles de reproducir y alcancen una mayor recepción entre los diversos públicos, en forma de vídeos virales que terminan siendo debatidos y compartidos por las audiencias que actúan a favor o en contra de alguna propuesta electoral.

Igualmente, los spots se despliegan en el portal de videos en serie YouTube, sitio web de moda para cualquier aspirante a cargo de elección popular, en razón a la posibilidad de alcanzar millones de visualizaciones por un público cibernauta activo $\mathrm{y}$, algo novedoso en las campañas políticas modernas, la reutilización del spot por parte de los seguidores, quienes terminan reeditando y ajustando la pieza publicitaria, para obtener un material de difusión más original y acorde a sus gustos, lo cual conlleva a crear ambientes musicales, frases virales y jingles o coros pegajosos, que en última logran contagiar a las comunidades, hasta el punto de encerrarlos electoralmente con el candidato que consigue el objeto central del spot: captar votos en algún tipo de actor.

Recientemente, una experiencia a nivel internacional de spot pegajoso o reutilizado se dio durante la campaña presidencial de Barack Obama con el hit Yes We Can (Sí podemos) en el 2008. Sobre esto anotó Leyvi Castro Martínez (2012):

Himno "Yes we can", canción compuesta por el rapero will.i.am de los Black Eyed Peas, video dirigido por Jesse Dylan, una coreografía protagonizada por celebridades estadunidenses, y con un mensaje cuidadosamente seleccionado, Barack Obama habló con palabras de su discurso luego de las elecciones primarias de New Hampshire, no sólo en inglés sino en español y hasta en hebreo, buscando integrar bajo un mismo signo al pueblo estadunidense.

Obama integró un movimiento que hizo partícipe a gente pública, actores y cantantes, por citar sólo algunos: Leonardo Di Caprio, Jennifer Aniston, Eva Longoria, Pearl Jam, Bruce Springsteen, acercándose a músicos progresistas que lo apoyaron y trabajaron con él, pues creyeron en su proyecto y lo demostraron. Logró el aval de grandes personalidades políticas y del espectáculo como la familia Kennedy, Oprah Winfrey, el ex presidente Jimmy Carter, entre otros, que le redituaron en la legitimación de su campaña y su proyecto.

Figura 2. Spot "Yes we can" - Barack Obama 2008
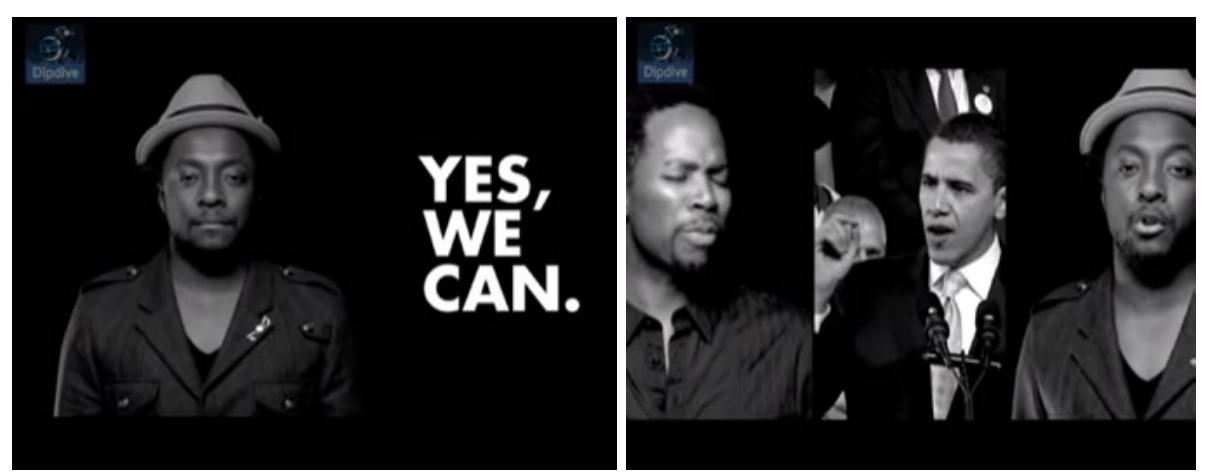

Recuperado de YouTube: Disponible en el siguiente enlace https://www.youtube.com/watch?v=jiXyqcx-mYY

En el contexto colombiano, las primeras experiencias de utilización del spot publicitario como estrategia de mercadeo político se remontan a finales de los años ochenta con la intervención de "asesores norteamericanos durante la presidencia de Virgilio Barco Vargas, el marketing político comenzó a ser introducido en las campañas electorales en Colombia” (Beccassino, 2003, p. 120). Es decir, antes de esa época, los aspirantes eran asesorados por su grupo exclusivo de amigos o parientes quienes aportaban un conocimiento empírico sobre los temas socio-políticos coyunturales destacados en la agenda nacional. Prácticamente, las campañas políticas de esa época carecían de profesionalismo en sus diversas líneas de acción. 
En este escenario, se empieza a dar la incursión de otras estrategias de visualización diferentes a las habituales pautas publicitarias divulgadas en los espacios informativos con mayor audiencia. El spot medio narrativo audiovisual, comenzó a ser implementado sustancialmente en la televisión colombiana al parecer en la campaña presidencial de 1990, cuando los candidatos Cesar Gaviria Trujillo y Carlos Pizarro Leongómez
(Figura 3) le apostaron a posicionar un mensaje de 30 segundos, algo que para la época solo se hacía en medios sonoros como la radio, a pesar de que, por un lado, la recepción televisiva ya cubría gran parte de del territorio, y por otra parte, existía una variedad de agencias productoras en televisión., que en su mayoría se especializaban en la realización de mensajes comerciales que enfatizaban en las bondades de ciertos productos.

Figura 3. Spot campaña presidencial Carlos Pizarro 1990
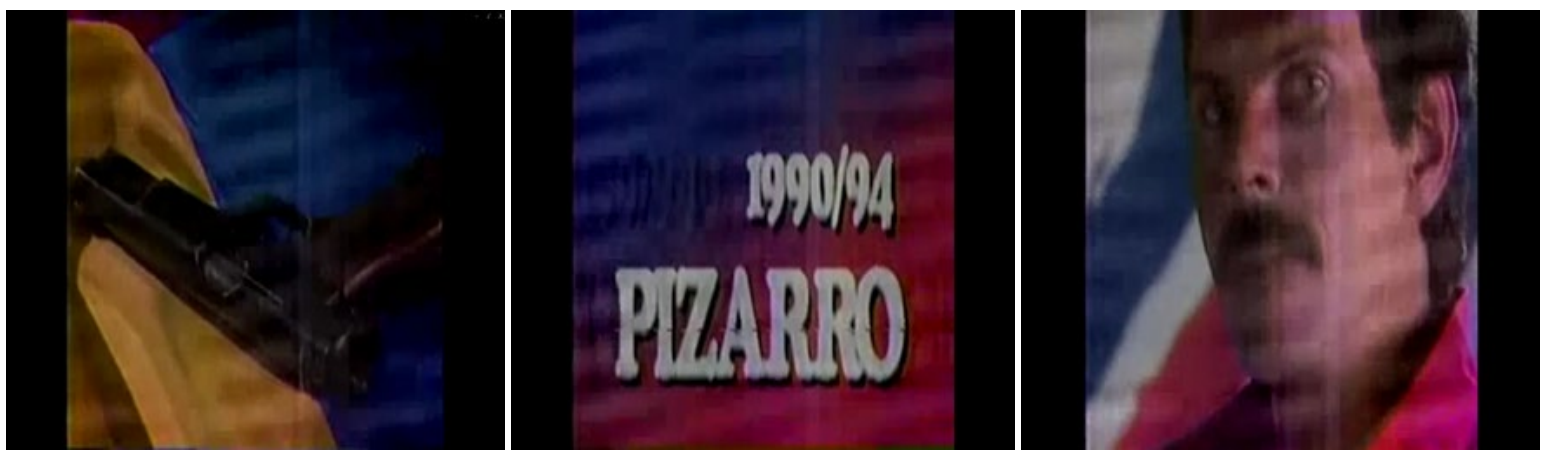

Recuperado de YouTube: Disponible en el siguiente enlace https://www.youtube.com/watch?v=teogv_Vv2PU

Entre las características técnicas del spot empleado por el candidato Carlos Pizarro se cuentan el desarrollo en 28 segundos; la permanente utilización de primerísimos primeros planos, es decir el 'busto parlante o talking head ads' que señala Patrick Devlin (1987), en los cuales el aspirante se dirige directamente a la cámara y habla de su propuesta; el uso de una frase contundente que cierra su intervención en el video: 'palabra que SÍ'. También se destacan dos elementos simbólicos o narrativos que estructuran el spot: su pistola $9 \mathrm{~mm}$ envuelta en la bandera de Colombia el día de la firma del acuerdo de paz en Corinto-Cauca. Pizarro, avalado por el partido Alianza Democrática M-19, hizo parte de la lista de los cuatro candidatos asesinados ante de las contiendas presidenciales del 27 de mayo de 1990, tras lo cual Antonio Navarro Wolff retomó la candidatura logrando 754.740 votos.

\section{Spots en las campañas electorales en Boyacá}

Rápidamente la moda de utilizar el spot en las campañas electorales transcendió a nivel local en los años noventa e inicios del nuevo milenio. Ya no era solamente una pieza publicitaria para visualizar la candidatura de algún pretendiente al primer cargo de elección popular en Colombia, sino que aspirantes a gobernaciones, asambleas, concejos municipales, alcaldías y Congreso de la República terminaron contagiándose del spot político igualmente.

Ello resulta visible precisamente durante la exposición activa de spots por parte de los candidatos al Congreso colombiano en las contiendas de 2014. A lo largo del proceso publicitario, aspirantes a la Cámara de Representantes y Senado de la República por Boyacá, sitúan en las diversas plataformas de las TIC, videos de 30 segundos,

donde el mensaje central estuvo relacionado con la identidad y preservación de la tradición boyacense, especialmente coincidiendo en adelantar propuestas sociales encaminadas a la búsqueda de mejorar las condiciones del sector agropecuario, principal receptor económico en la región. Asimismo estos mensajes se identificaron por llevar iconos representativos del departamento como la ruana que es un abrigo o manta cuadrada artesanal hecha de lana, el sombrero y amplias extensiones agrícolas que embellecen los paisajes. También se destaca el acompañamiento de ritmos musicales muy autóctonos, como el torbellino, la rumba, la carranga, entre otros (Lozano García, 2014, pp. 167-168).

Otros elementos característicos y técnicos encontrados en esta nueva generación de spots publicitarios desarrollados por los candidatos boyacenses en el 2014, fue la circulación de piezas 
por las redes sociales Facebook, Twitter, Instagram y el sitio web YouTube. Tales escenarios de visualización son alimentados con videos que muestran capacidades de liderazgo, cualidades personales, ideales políticos, gestión, animación, utilización de herramientas de la Web 2.0 o 3.0, diversidad de planos abordados, y relatos testimoniales; todo lo anterior terminó siendo articulado por la mayoría de aspirantes que le apostaron al spot como estrategia de captar votos (ver Figura 4).

Figura 4. Muestras de spots - candidatos Congreso 2014
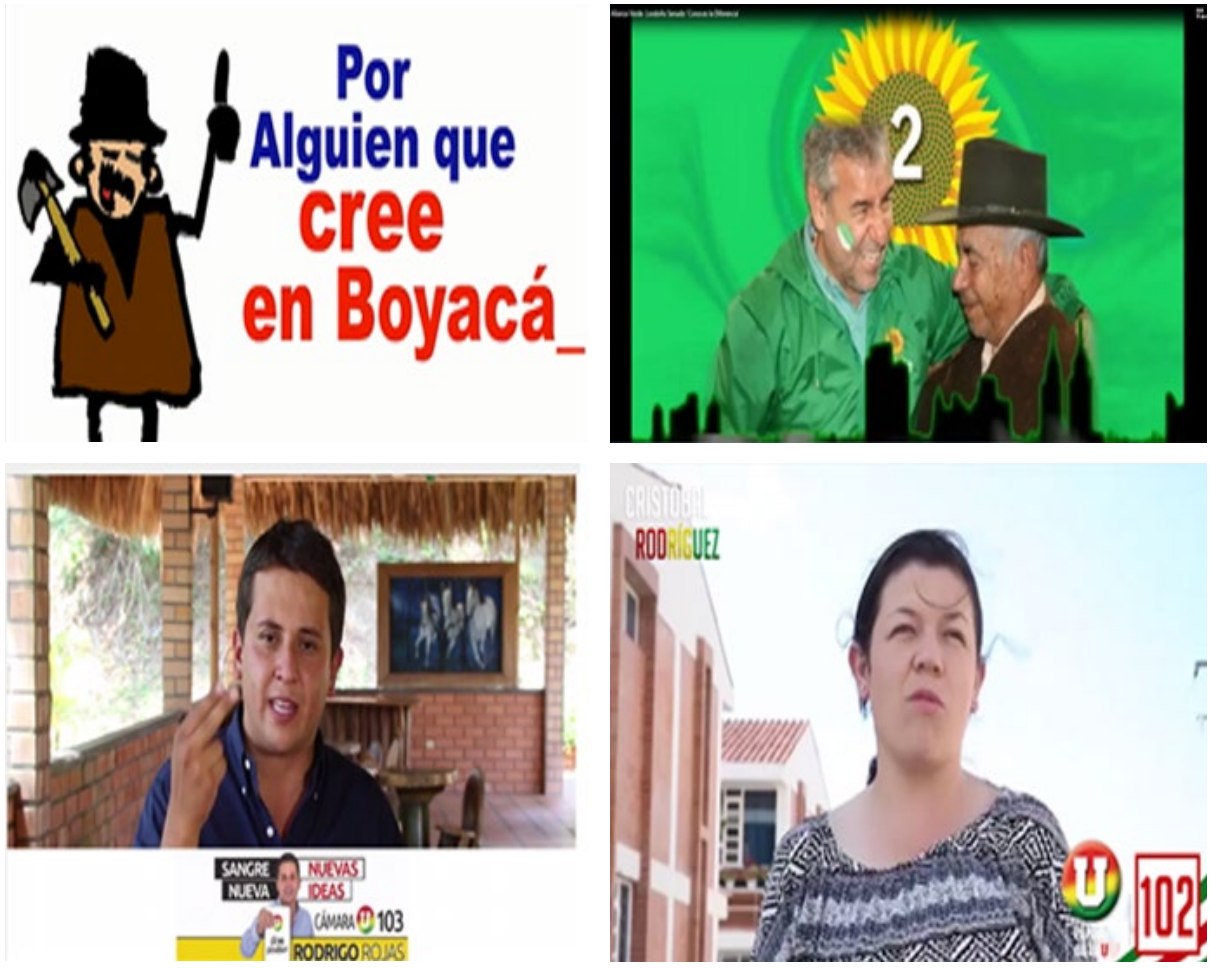

Imágenes recuperadas de las cuentas de redes sociales de candidatos

En este sentido, el auge de las TIC a nivel global viene transformando los modos de uso del spot publicitario de candidatos boyacenses. Ahora los equipos de campaña comparten, dentro del mismo formato de treinta segundos, efectos especiales, intervención de seguidores y hasta animaciones en $3 \mathrm{D}$, que entretejen una relación directa con el posible público votante, lo que establece un ecosistema mediático electoral que promueve una circulación de códigos y mensajes de forma multidireccional. En otras palabras, se genera una participación e interacción entre candidatos y electores por medios de las redes sociales, algo novedoso que tuvieron las campañas al Congreso del 2014, donde el ciber activismo prácticamente avanzó en la renovación de la cultura política en Boyacá.

Justamente, Mariano Cebrián Herreros destacó el término de ecosistema mediático electoral, el cual surge a raíz de que el "empobrecimiento en los medios tradicionales tuvo su correlato en los cibermedios controlados por los propios partidos tanto a través de la web general y de los espacios abiertos a los candidatos, como de sus canales de radio y televisión y de sus blogs institucionales o de los promovidos por afiliados o simpatizantes del partido" (2012, p. 11). Es decir, el ecosistema mediático electoral permitió incorporar las redes sociales y la telefonía móvil para mejorar los procesos comunicativos entre los diversos actores comprometidos en el debate; a su vez, este ecosistema ha generado nuevas herramientas de desarrollo de piezas informativas, desde el software libre que facilita la labor del equipo de campaña y los grupos de seguidores, quienes ejercen libertad en cuanto a la circulación de mensajes, algo opuesto al modo de proceder en los medios tradicionales, cuando los mensajes a difundir eran aprobados en los filtros del gatekeeper o 'seleccionador de noticias'. 


\section{Los spots desde las teorias y elementos metodológicos}

Evidentemente, las elecciones al Congreso de la República 2018 en Colombia consolidaron el uso de las TIC directamente en los grupos de apoyo que envolvieron a las campañas y obviamente a los propios candidatos. Es notoria la profesionalización de las campañas electorales, especialmente en la apropiación de la publicidad política en los medios comunicativos de última era. El caso de la participación activa que tuvieron la mayoría de candidatos al Congreso por Boyacá demuestra la disposición de la tecnología digital en los procesos electivos, que llevan ahora a la incorporación de nuevas estrategias de captación de votos, tales como tener espacios web especializados, intervenir en calidad de youtubers, manejar perfiles en las redes que registran diversidad de contenidos o formatos de mensajes.

En lo que concierne a intervenir como youtubers, Rubí Gutiérrez (como se citó en Suárez Tello, 2018), señala en un estudio realizado por Google que,

el número de reproducciones por YouTube ha superado a la audiencia de la televisión por cable en Estados Unidos. Quizá el principal motivo de este cambio haya sido el aumento del uso del teléfono móvil y el uso de las tabletas para disfrutar de los contenidos de YouTube sin restricción de horario ni ubicación. Por si fuera poco, estos datos reflejan que los visitantes se multiplican por tres, año tras año. Algo que también lo hace es el tiempo de reproducción de vídeo, creciendo un $60 \%$ desde el año pasado. Hoy, cualquiera puede transmitir contenidos de YouTube y tener su propio canal, pero la categoría de influencers se da por el número de suscriptores que se tengan a los contenidos que se producen. Muchos de estos YouTubers que han llegado a ser influencers generan mucho más audiencia que los programas y series de televisión más populares.

Lo anterior permite entender la lógica $\mathrm{y}$ dinámica de los candidatos boyacenses que se valieron de los spots, aprovechando las ventajas de YouTube, en cuanto al manejo gratis de la información divulgada, la facilidad de uso, la cómoda navegación, el hecho de ser el portal web más visitado por el público cibernauta y la calificación de los videos (más vistos, más comentados, favoritos). Estos argumentos favorecen la articulación del canal con las campañas políticas, forjando una herramienta fundamental en el mercadeo electoral. Xabier Peytibi sostiene que YouTube ha demostrado convertirse en un ágora donde las informaciones a través de vídeos, también sobre política, podían ser una excelente opción para las campañas electorales. En pocos años, esta web había pasado a ser algo fundamental en el entretenimiento de toda una nueva generación, que navegaba por la red e interaccionaba en ella (2016, p. 169).

Ahora bien, los ejemplos de spots estudiados en las siguientes líneas demuestran la variedad de piezas publicitarias empleadas por los candidatos de Boyacá al Congreso de la República 2018. Para ello, metodológicamente se relacionan teorías o tipologías que son articuladas a los spots pesquisados en el proceso electoral que duró tres meses, conforme a la Ley 130 de 1994 (marzo 23)리 la cual reglamenta los periodos para llevar a cabo la propaganda electoral. La información arrojada permitió identificar más de 20 spots entre los aspirantes al Senado y Cámara de Representantes, de los cuales se han seleccionado y procesado 10 en la matriz Caracterización de los spots electorales que recoge los datos teóricos y técnicos de cada video.

Las piezas seleccionadas fueron halladas en las diversas cuentas de redes sociales, páginas webs, blogs digitales de aspirantes boyacenses, partiendo de los elementos técnicos que identifican los spots políticos, como tiempo de duración (aproximadamente 30 segundos), musicalización, imágenes, tono, género, enunciador (candidato o partido político), y mensajes políticos. Luego, se debatieron desde un enfoque cualitativo las categorías y elementos que componen los spots a partir de los postulados teóricos relacionados con la comunicación política.

Precisamente, dentro de los aportes teóricos desarrollados, sobre las historias que logran ser contadas en los videos Christian Salmon (2008) señala que "contar una historia es cómo se construye la imagen en la actualidad: la narración como una manera de convencer y movilizar a la opinión pública”. Por otro lado, José Adolfo Ibinarriaga y Roberto Trad Hasbun (2012) destacan siete códigos comunicativos básicos que llevan de manera explícita e implícita los spots:

1. Título VI.

De la publicidad, la propaganda y las encuestas políticas Artículo 24. Propaganda electoral. Entiéndese por propaganda electoral la que realicen los partidos, los movimientos políticos y los candidatos a cargos de elección popular y las personas que los apoyen, con fin de obtener apoyo electoral. partidos, los movimientos politicos y los candidatos a cargos de eleccion popular y las personas que los apoyen, con fin de obten
Esta clase de propaganda electoral únicamente podrá realizarse durante los tres (3) meses anteriores a la fecha de las elecciones. 
1. Lenguaje lingüístico: discurso verbal, contenido y argumentos.

2. Lenguaje kinésico: movimientos y expresiones físicas, durante el discurso o en silencio.

3. Lenguaje proxémico: corresponde al uso y organización del espacio físico (cerca de personas, sentados, mesa de trabajo o equipo).

4. Lenguaje iridológico: contacto visual entre el entrevistador, directamente a la cámara, o a las comunidades.

5. Lenguaje fisiológico: características morfológicas de una persona que deben ser consideradas.

6. Moda: ropa o estética personal, vestuario, apariencias, y demás objetos comunicativos.

7. Valores no verbales de la voz:, tono, volumen, entonación.

Los códigos comunicativos serán acompañados de siete tipologías de spot que recoge Patrick Devlin (1987) tras analizar los anuncios de campaña de las presidenciales estadounidenses entre 1952 y 1984 (como se citó en Peña, 2011, pp. 4-6). Las piezas publicitarias en su orden son:
1. Busto parlante o talking head ads: el candidato se dirige directamente "a cámara" y habla de su programa, de su partido o de sí mismo.

2. Cinéma verité: un paseo por la vida del candidato (en el despacho, en el campo, en familia, etc.) con el que se pretende dar apariencia real.

3. Anuncios documentales: dan cuenta de los logros obtenidos por el candidato.

4. Hombre de la calle: se presentan ciudadanos comunes que hablan a favor del candidato. Generalmente se trata de actores profesionales contratados al efecto.

5. Porción de vida: el candidato simula una situación real, natural y cotidiana.

6. Testimoniales: ofrecen testimonios de apoyo al candidato expresados por diversas personalidades públicas.

7. Bio spot: se trata de una suerte de presentación en sociedad de candidatos nuevos o desconocidos.

Tabla 1. Caracterización de los spots electorales

\begin{tabular}{|c|c|c|c|c|c|c|c|c|c|c|}
\hline $\begin{array}{l}\text { Carac- } \\
\text { teristicas } \\
\text { teóricas y } \\
\text { técnicas } \\
\text { del spot }\end{array}$ & $\begin{array}{c}\text { Spot } 1 \\
\text { Yo voto } \\
\text { por la ren- } \\
\text { ovación }\end{array}$ & $\begin{array}{c}\text { Spot } 2 \\
\text { Porque } \\
\text { vas a } \\
\text { votar }\end{array}$ & $\begin{array}{l}\text { Spot } 3 \\
\text { Boyacá } \\
\text { razón de } \\
\text { lucha }\end{array}$ & $\begin{array}{c}\text { Spot } 4 \\
\text { Como } \\
\text { votar al } \\
\text { Senado }\end{array}$ & $\begin{array}{c}\text { Spot } 5 \\
11 \text { de } \\
\text { marzo la } \\
\text { partida }\end{array}$ & $\begin{array}{l}\text { Spot } 6 \\
\text { Mi- } \\
\text { gración } \\
\text { digna } \\
\text { verde }\end{array}$ & $\begin{array}{l}\text { Spot } 7 \\
\text { Voto } \\
\text { consci- } \\
\text { ente }\end{array}$ & $\begin{array}{c}\text { Spot } 8 \\
\text { Saludo } \\
\text { navideño } \\
\text { Hernán- } \\
\text { dez }\end{array}$ & $\begin{array}{l}\text { Spot } 9 \\
106 \text { se- } \\
\text { gundos } \\
\text { con Ro- } \\
\text { jas }\end{array}$ & $\begin{array}{l}\text { Spot } 10 \\
\text { Apoyo de } \\
\text { Antanas } \\
\text { Mockus }\end{array}$ \\
\hline $\begin{array}{l}\text { Historias } \\
\text { contadas }\end{array}$ & $\begin{array}{l}\text { Apoyo al } \\
\text { candida- } \\
\text { to de la } \\
\text { renovación } \\
\text { por diversos } \\
\text { grupos }\end{array}$ & $\begin{array}{l}\text { Votar el } 12 \\
\text { de marzo } \\
\text { 'el voto } \\
\text { cuenta' }\end{array}$ & $\begin{array}{c}\text { Razón } \\
\text { para seguir } \\
\text { luchando: } \\
\text { proyectos } \\
\text { de vivienda } \\
\text { para Boyacá }\end{array}$ & $\begin{array}{l}\text { Votar el } 11 \\
\text { de marzo, } \\
\text { no votar en } \\
\text { blanco }\end{array}$ & $\begin{array}{l}\text { Votar por } \\
\text { la mejor } \\
\text { partida }\end{array}$ & $\begin{array}{l}\text { Votar por la } \\
\text { Cámara en } \\
\text { el exterior } \\
\text { (circuns- } \\
\text { cripción) }\end{array}$ & $\begin{array}{c}\text { Vota } \\
\text { bien, vota } \\
\text { diferente }\end{array}$ & $\begin{array}{c}\text { Saludo } \\
\text { navideño }\end{array}$ & $\begin{array}{l}\text { Presen- } \\
\text { tación de } \\
\text { Rodrigo } \\
\text { Rojas }\end{array}$ & $\begin{array}{l}\text { Unión del } \\
\text { Partido } \\
\text { Verde en } \\
\text { Boyacá }\end{array}$ \\
\hline $\begin{array}{l}\text { Lenguaje } \\
\text { lingüistico }\end{array}$ & $\begin{array}{l}\text { Apoyo } \\
\text { a Juan } \\
\text { Fernando } \\
\text { Jiménez }\end{array}$ & $\begin{array}{l}\text { Votar } \\
\text { Cuenta }\end{array}$ & $\begin{array}{l}\text { Viviendas } \\
\text { para Boyacá }\end{array}$ & $\begin{array}{l}\text { Con } \\
\text { Mira, la } \\
\text { política es } \\
\text { haciendo }\end{array}$ & $\begin{array}{c}\text { Vota por } \\
\text { Nasly } \\
\text { Cardoso, } \\
\text { Cambio } \\
\text { Radical } \\
106\end{array}$ & $\begin{array}{l}\text { Votar por } \\
\text { candidato a } \\
\text { la Cámara } \\
\text { en el exte- } \\
\text { rior }\end{array}$ & $\begin{array}{c}\text { Votar, es } \\
\text { pensar en } \\
\text { Boyacá }\end{array}$ & $\begin{array}{l}\text { Olegario } \\
\text { Hernández } \\
\text { Díaz, lo } \\
\text { nuevo a la } \\
\text { Cámara }\end{array}$ & $\begin{array}{c}\text { Rodrigo } \\
\text { Rojas, en } \\
\text { una sola } \\
\text { palabra }\end{array}$ & $\begin{array}{c}\text { Apoyo a Fa- } \\
\text { bio Antonio } \\
\text { Guerrero a } \\
\text { la Cámara } \\
\text { de Repre- } \\
\text { sentantes }\end{array}$ \\
\hline $\begin{array}{l}\text { Lenguaje } \\
\text { kinésico }\end{array}$ & $\begin{array}{l}\text { El candidato } \\
\text { no habla, } \\
\text { aparece en } \\
\text { fotografías, } \\
\text { intervienen } \\
\text { grupos de } \\
\text { apoyo }\end{array}$ & $\begin{array}{c}\text { La } \\
\text { candidata } \\
\text { aparece } \\
\text { caminan- } \\
\text { do frente a } \\
\text { la cámara } \\
\text { en los } \\
\text { últimos } 15 \\
\text { segundos, } \\
\text { hablando y } \\
\text { moviendo } \\
\text { sus brazos }\end{array}$ & $\begin{array}{c}\text { Sentando } \\
\text { de espalda } \\
\text { a la cámara } \\
\text { en un auto- } \\
\text { móvil (en } \\
\text { movimien- } \\
\text { to), ubicado } \\
\text { en el puesto } \\
\text { del lado } \\
\text { derecho }\end{array}$ & $\begin{array}{c}\text { No se } \\
\text { muestra } \\
\text { ningún } \\
\text { movi- } \\
\text { miento, el } \\
\text { candidato } \\
\text { aparece en } \\
\text { voz en off. }\end{array}$ & $\begin{array}{l}\text { Destreza } \\
\text { para } \\
\text { mover las } \\
\text { fichas de } \\
\text { ajedrez }\end{array}$ & $\begin{array}{l}\text { De pie con } \\
\text { los dedos } \\
\text { cruzados } \\
\text { (manos) }\end{array}$ & $\begin{array}{c}\text { De pie, } \\
\text { mueve } \\
\text { los brazos } \\
\text { para hablar }\end{array}$ & $\begin{array}{c}\text { Sonríe, } \\
\text { y mueve } \\
\text { sus manos } \\
\text { 'señalán- } \\
\text { dose', como } \\
\text { candidato }\end{array}$ & $\begin{array}{l}\text { Sonríe, } \\
\text { aparece } \\
\text { sentado } \\
\text { y mueve } \\
\text { su brazo } \\
\text { derecho }\end{array}$ & $\begin{array}{l}\text { El can- } \\
\text { didato } \\
\text { aparece en } \\
\text { fotografía } \\
\text { 'congela }\end{array}$ \\
\hline $\begin{array}{l}\text { Lenguaje } \\
\text { proxémico }\end{array}$ & $\begin{array}{l}\text { Hay perso- } \\
\text { nas ubicadas } \\
\text { en espacios } \\
\text { abiertos de } \\
\text { Tunja, hay } \\
\text { fotos del } \\
\text { candidato en } \\
\text { reuniones } \\
\text { grupales }\end{array}$ & $\begin{array}{l}\text { Aparece } \\
\text { sola en un } \\
\text { espacio } \\
\text { de fondo } \\
\text { blanco }\end{array}$ & $\begin{array}{l}\text { Hablando } \\
\text { dentro de un } \\
\text { automóvil e } \\
\text { intervención } \\
\text { en tarima }\end{array}$ & No aplica & $\begin{array}{c}\text { Campo } \\
\text { abierto, } \\
\text { centro } \\
\text { histórico } \\
\text { de Tunja, } \\
\text { comparte } \\
\text { un juego } \\
\text { de ajedrez }\end{array}$ & $\begin{array}{l}\text { Comparte } \\
\text { el espacio } \\
\text { con Jorge } \\
\text { Eduardo } \\
\text { Londoño } \\
\text { (candidato } \\
\text { al Senado) }\end{array}$ & $\begin{array}{c}\text { Sola } \\
\text { rodeada de } \\
\text { vegetación }\end{array}$ & $\begin{array}{c}\text { Está solo, lo } \\
\text { acompa- } \\
\text { ña una } \\
\text { animación } \\
\text { o efectos } \\
\text { navideño }\end{array}$ & $\begin{array}{l}\text { Al parecer } \\
\text { se encuen- } \\
\text { tra en su } \\
\text { residencia } \\
\text { y aparece } \\
\text { solo. }\end{array}$ & $\begin{array}{l}\text { Aparece en } \\
\text { fotogra- } \\
\text { fía con } \\
\text { Antanas } \\
\text { Mockus }\end{array}$ \\
\hline
\end{tabular}




\begin{tabular}{|c|c|c|c|c|c|c|c|c|c|c|}
\hline $\begin{array}{l}\text { Lenguaje } \\
\text { iridológico }\end{array}$ & No aplica & $\begin{array}{l}\text { Se ubica } \\
\text { directa- } \\
\text { mente a la } \\
\text { cámara de } \\
\quad \text { video }\end{array}$ & $\begin{array}{c}\text { De espalda } \\
\text { a la cámara } \\
\text { y en plano } \\
\text { general }\end{array}$ & No aplica & $\begin{array}{l}\text { No registra } \\
\text { mirada } \\
\text { ante la } \\
\text { cámara, } \\
\text { mirando el } \\
\text { tablero de } \\
\text { ajedrez }\end{array}$ & $\begin{array}{c}\text { Mira direc- } \\
\text { tamente a } \\
\text { la cámara } \\
\text { (fijación) }\end{array}$ & $\begin{array}{l}\text { Mira di- } \\
\text { rectamente } \\
\text { a la cámara } \\
\text { de video } \\
\text { (fijación) }\end{array}$ & $\begin{array}{l}\text { Se enfoca } \\
\text { directa- } \\
\text { mente a la } \\
\text { cámara }\end{array}$ & $\begin{array}{c}\text { Mira direc- } \\
\text { tamente a } \\
\text { la cámara } \\
\text { de video }\end{array}$ & $\begin{array}{l}\text { Solo foto- } \\
\text { grafía }\end{array}$ \\
\hline $\begin{array}{l}\text { Lenguaje } \\
\text { fisiológico }\end{array}$ & $\begin{array}{l}\text { Candidato } \\
\text { joven adulto }\end{array}$ & $\begin{array}{l}\text { Mujer } \\
\text { joven }\end{array}$ & $\begin{array}{l}\text { Adulto } \\
\text { mayor }\end{array}$ & $\begin{array}{l}\text { Candidato } \\
\text { joven } \\
\text { adulto }\end{array}$ & $\begin{array}{l}\text { Mujer } \\
\text { joven } \\
\text { adulta }\end{array}$ & $\begin{array}{l}\text { Adulto } \\
\text { mayor }\end{array}$ & $\begin{array}{c}\text { Mujer jo- } \\
\text { ven adulta, } \\
\text { contextura } \\
\text { física } \\
\text { grande }\end{array}$ & $\begin{array}{c}\text { Adulto } \\
\text { mayor, } \\
\text { demuestra } \\
\text { seguridad }\end{array}$ & $\begin{array}{l}\text { Joven } \\
\text { adulto }\end{array}$ & $\begin{array}{l}\text { Adulto } \\
\text { mayor }\end{array}$ \\
\hline Moda & $\begin{array}{c}\text { Aspecto } \\
\text { físico atrac- } \\
\text { tivo y joven, } \\
\text { vestido } \\
\text { informal, } \\
\text { utiliza el co- } \\
\text { lor blanco. }\end{array}$ & $\begin{array}{l}\text { Vestida } \\
\text { informal- } \\
\text { mente, con } \\
\text { camisa } \\
\text { blanca y } \\
\text { chaleco } \\
\text { publicita- } \\
\text { rio color } \\
\text { azul }\end{array}$ & $\begin{array}{l}\text { Camisa y } \\
\text { fondo blanco } \\
\text { en el afiche } \\
\text { promocional } \\
\text { de la campa- } \\
\text { na, también } \\
\text { viste una } \\
\text { ruana }\end{array}$ & $\begin{array}{l}\text { Candidato } \\
\text { en fotos } \\
\text { vestido } \\
\text { informal- } \\
\text { mente con } \\
\text { camisa y } \\
\text { pantalón } \\
\text { de color } \\
\text { azul }\end{array}$ & $\begin{array}{l}\text { Vestida } \\
\text { informal, } \\
\text { chaqueta } \\
\text { de color } \\
\text { rojo, tono } \\
\text { que uso en } \\
\text { sus afiches }\end{array}$ & $\begin{array}{c}\text { Camisa } \\
\text { de color } \\
\text { blanco, } \\
\text { utiliza un } \\
\text { botón pu- } \\
\text { blicitario, } \\
\text { logotipo } \\
\text { del Partido } \\
\text { Verde }\end{array}$ & $\begin{array}{c}\text { Camisa de } \\
\text { color rojo, } \\
\text { el tono que } \\
\text { representa } \\
\text { el Partido } \\
\text { Liberal que } \\
\text { avaló su } \\
\text { candida- } \\
\text { tura }\end{array}$ & $\begin{array}{c}\text { Aparece } \\
\text { con traje } \\
\text { formal }\end{array}$ & $\begin{array}{l}\text { Camisa } \\
\text { blanca, } \\
\text { estampada } \\
\text { con el } \\
\text { logo de } \\
\text { campaña y } \\
\text { el símbolo } \\
\text { del Partido } \\
\text { Liberal }\end{array}$ & $\begin{array}{l}\text { Camisa } \\
\text { verde con } \\
\text { el logo del } \\
\text { Partido } \\
\text { Verde }\end{array}$ \\
\hline $\begin{array}{l}\text { Valores no } \\
\text { verbales de } \\
\text { la voz }\end{array}$ & No aplica & $\begin{array}{l}\text { Acen- } \\
\text { tuación: } \\
\text { Patricia } \\
\text { Guerrero, } \\
\text { está con } \\
\text { los jóvenes }\end{array}$ & $\begin{array}{c}\text { Habla pausa- } \\
\text { do, y recalca } \\
\text { solucionas } \\
\text { de viviendas }\end{array}$ & $\begin{array}{l}\text { Voz pau- } \\
\text { sada }\end{array}$ & $\begin{array}{l}\text { No hay } \\
\text { registro de } \\
\text { la voz de la } \\
\text { candidata. } \\
\text { Aparece } \\
\text { voz en } \\
\text { off de } \\
\text { cantante } \\
\text { acentuan- } \\
\text { do en } \\
\text { Boyacá } \\
\text { será mejor }\end{array}$ & $\begin{array}{l}\text { Su voz se } \\
\text { escucha } \\
\text { en los } \\
\text { últimos } 10 \\
\text { segundos } \\
\text { del video, } \\
\text { a modo } \\
\text { pausado } \\
\text { le hace } \\
\text { publicidad } \\
\text { a Londoño }\end{array}$ & $\begin{array}{l}\text { Menciona } \\
\text { frases } \\
\text { cortadas, } \\
\text { con realce, } \\
\text { termina } \\
\text { haciendo } \\
\text { énfasis en } \\
\text { la frase: } \\
\text { piensa en } \\
\text { Boyacá }\end{array}$ & $\begin{array}{c}\text { Entona- } \\
\text { ción: para } \\
\text { la Cámara } \\
\text { de Repre- } \\
\text { sentantes, } \\
\text { ¡lo nuevo;, } \\
\text { Olegario } \\
\text { Hernández } \\
\text { Díaz }\end{array}$ & $\begin{array}{l}\text { Voz } \\
\text { lineal, con } \\
\text { respuestas } \\
\text { de frases } \\
\text { cortas }\end{array}$ & $\begin{array}{l}\text { No aplica, } \\
\text { solo habla } \\
\text { Mockus }\end{array}$ \\
\hline $\begin{array}{c}\text { Busto } \\
\text { parlante } \\
\text { o talking } \\
\text { head ads }\end{array}$ & No aplica & $\begin{array}{c}\text { La } \\
\text { candidata } \\
\text { destaca } \\
\text { que está } \\
\text { con los } \\
\text { jóvenes }\end{array}$ & $\begin{array}{l}\text { Habla de } \\
\text { espalda a la } \\
\text { cámara }\end{array}$ & No aplica & No aplica & $\begin{array}{c}\text { Solo } \\
\text { comenta } \\
\text { votar por } \\
\text { Londoño }\end{array}$ & $\begin{array}{c}\text { La } \\
\text { candidata } \\
\text { habla en } \\
\text { 'pensar en } \\
\text { Boyacá' }\end{array}$ & $\begin{array}{l}\text { Candidato } \\
\text { destaca } \\
\text { que } \\
\text { representa } \\
\text { lo nuevo }\end{array}$ & $\begin{array}{l}\text { En } 106 \\
\text { segundos } \\
\text { aborda } \\
\text { sobre la } \\
\text { propuesta }\end{array}$ & No aplica \\
\hline $\begin{array}{l}\text { Cinéma } \\
\text { verité }\end{array}$ & $\begin{array}{l}\text { Correrías } \\
\text { electorales } \\
\text { con distin- } \\
\text { tos tipos de } \\
\text { públicos }\end{array}$ & No aplica & No aplica & No aplica & $\begin{array}{l}\text { Candidata } \\
\text { que juega } \\
\text { ajedrez }\end{array}$ & No aplica & $\begin{array}{l}\text { Todos } \\
\text { tenemos } \\
\text { un voto, a } \\
\text { todos nos } \\
\text { entregan } \\
\text { un tar- } \\
\text { jetón, tú } \\
\text { decides }\end{array}$ & No aplica & $\begin{array}{l}\text { Habla de } \\
\text { la familia } \\
\text { y personas } \\
\text { que } \\
\text { admira }\end{array}$ & $\begin{array}{c}\text { En la } \\
\text { fotografía } \\
\text { se muestra } \\
\text { como un } \\
\text { candidato } \\
\text { de partido } \\
\text { político }\end{array}$ \\
\hline $\begin{array}{l}\text { Anuncios } \\
\text { documen- } \\
\text { tales }\end{array}$ & No aplica & No aplica & $\begin{array}{c}\text { Comenta } \\
\text { sus logros } \\
\text { en vivienda }\end{array}$ & No aplica & $\begin{array}{l}\text { Juega } \\
\text { ajedrez }\end{array}$ & No aplica & No aplica & $\begin{array}{l}\text { Se muestra } \\
\text { con expe- } \\
\text { riencia }\end{array}$ & $\begin{array}{l}\text { Fue ele- } \\
\text { gido a los } \\
26 \text { años } \\
\text { Diputado }\end{array}$ & No aplica \\
\hline $\begin{array}{l}\text { Hombre de } \\
\text { la calle }\end{array}$ & $\begin{array}{c}\text { Comer- } \\
\text { ciantes, } \\
\text { deportistas, } \\
\text { ambu- } \\
\text { lantes y } \\
\text { animalistas } \\
\text { intervienen }\end{array}$ & $\begin{array}{c}\text { Grupos } \\
\text { de jóvenes }\end{array}$ & No aplica & No aplica & $\begin{array}{l}\text { Ciudada- } \\
\text { nos que } \\
\text { juegan } \\
\text { ajedrez } \\
\text { con la } \\
\text { candidata }\end{array}$ & No aplica & No aplica & No aplica & No aplica & $\begin{array}{l}\text { Apoya- } \\
\text { do por } \\
\text { dirigentes } \\
\text { del Partido } \\
\text { Verde }\end{array}$ \\
\hline $\begin{array}{l}\text { Porción de } \\
\text { vida }\end{array}$ & $\begin{array}{l}\text { Espacios } \\
\text { con las co- } \\
\text { munidades, } \\
\text { 'defensor de } \\
\text { animales' }\end{array}$ & No aplica & $\begin{array}{l}\text { Hay relato } \\
\text { de sus lo- } \\
\text { gros como } \\
\text { Congresista } \\
\text { en ejercicio }\end{array}$ & $\begin{array}{c}\text { El } \\
\text { candidato } \\
\text { simula } \\
\text { estar o } \\
\text { apoyar al } \\
\text { campo }\end{array}$ & $\begin{array}{c}\text { Estar } \\
\text { jugando } \\
\text { ajedrez en } \\
\text { espacio } \\
\text { abierto }\end{array}$ & No aplica & No aplica & $\begin{array}{c}\text { El } \\
\text { candidato } \\
\text { simula } \\
\text { compartir } \\
\text { momentos } \\
\text { navideños }\end{array}$ & $\begin{array}{l}\text { Hay si- } \\
\text { mulación } \\
\text { de si vida } \\
\text { personal y } \\
\text { política }\end{array}$ & No aplica \\
\hline
\end{tabular}




\begin{tabular}{|c|c|c|c|c|c|c|c|c|c|c|}
\hline $\begin{array}{l}\text { Testimoni- } \\
\text { ales }\end{array}$ & No aplica & No aplica & $\begin{array}{c}\text { Intervienen } \\
\text { los alcaldes } \\
\text { Luis Mario } \\
\text { Vargas } \\
\text { (Floresta) } \\
\text { y Pedro } \\
\text { López } \\
\text { (Campo- } \\
\text { hermoso), } \\
\text { y la imagen } \\
\text { del excan- } \\
\text { didato a la } \\
\text { presidencia } \\
\text { German } \\
\text { Vargas } \\
\text { Lleras }\end{array}$ & No aplica & No aplica & $\begin{array}{c}\text { Interviene } \\
\text { Jorge } \\
\text { Eduardo } \\
\text { Londoño, } \\
\text { ex Gober- } \\
\text { nador de } \\
\text { Boyacá, } \\
\text { quién } \\
\text { invita a } \\
\text { votar por } \\
\text { Manuel... }\end{array}$ & $\begin{array}{l}\text { La candi- } \\
\text { data inter- } \\
\text { viene en } \\
\text { el campo }\end{array}$ & No aplica & No aplica & $\begin{array}{c}\text { Mockus } \\
\text { destaca al } \\
\text { candidato: } \\
\text { Fabio } \\
\text { Antonio } \\
\text { Guerrero, } \\
\text { es una per- } \\
\text { sona que } \\
\text { tiene una } \\
\text { trayectoria } \\
\text { muy desta- } \\
\text { cada... }\end{array}$ \\
\hline
\end{tabular}

\begin{tabular}{|c|c|c|c|c|c|c|c|c|c|c|}
\hline Bio spot & $\begin{array}{l}\text { La comu- } \\
\text { nidad lo } \\
\text { presenta }\end{array}$ & No aplica & No aplica & No aplica & $\begin{array}{c}\text { Se presen- } \\
\text { ta como } \\
\text { conoce- } \\
\text { dora del } \\
\text { ajedrez }\end{array}$ & $\begin{array}{l}\text { Londoño } \\
\text { lo presenta } \\
\text { como } \\
\text { candidato }\end{array}$ & No aplica & $\begin{array}{c}\text { Se presen- } \\
\text { ta como lo } \\
\text { nuevo en } \\
\text { la política }\end{array}$ & No aplica & No aplica \\
\hline
\end{tabular}

Fuente: Elaboración propia con información tomada de spots de candidatos.

\section{Discusión y resultados de la matriz}

Con base en los principales datos arrojados por la matriz Caracterización de los spots electorales (Tabla 1), se discuten en su orden las 'historias comunes' que significaron la construcción de elementos narrativos expuestos en cada spot. Las historias comunes referentes a los procesos políticos y, lógicamente, a las elecciones en Boyacá, fueron evidentes en las representaciones diarias y coyunturales que rodearon las elecciones para el Congreso 2018 en Colombia. Estas historias partieron de la concentración de una agenda pública y política local que involucró issues ligados a las necesidades sociales en el departamento de Boyacá, descredito de la clase política tradicional y mediatización referente a temas acerca de la corrupción. Precisamente este último tópico marcó la agenda con la producción de mensajes implícitos en contra de la corrupción basados en propuestas electorales novedosas orientadas hacía la 'renovación' del Congreso colombiano: Apoyo al candidato de la renovación por diversos grupos sociales (spot 1) [de ahora en adelante \#], vota bien, vota diferente (\# 7), Unión del Partido Verde en Boyacá (\# 10), y Votar el 11 de marzo, no votar en blanco (\# 4); en los temas secundarios, sobresale el \#3: Una razón para seguir luchando: proyectos de vivienda para Boyacá, programa de 'vivienda social' que adelantó el gobierno del expresidente Juan Manuel Santos entre los años 2014 a 2018.

Dentro del 'lenguaje lingüístico', existe coincidencia entre los discursos audiovisuales de los spots que promovieron el voto como mecanismo de participación ciudadana o votar por alguna opción electoral. Prueba de ello son las muestras: votar cuenta (\# 2) orientado al voto participativo; en cuanto a votar por opciones pueden señalarse: vota por Nasly Cardoso, Cambio Radical 106 (\# 5), Votar por candidato a la Cámara en el exterior (\# 6), Votar, es pensar en Boyacá (\# 7). Esta coherencia discursiva, logra interpretarse desde la apatía política que ha caracterizado a los últimos debates nacionales, en los que los ciudadanos manifiestan su inconformismo con la clase política mediante la abstención electoral, votando en blanco o anulando el tarjetón a modo de 'voto protesta o bronca'. A lo anterior se suma la imagen negativa de los partidos o movimientos que abanderan las candidaturas, argumento de los votantes para resistirse a intervenir en las distintas formas de sufragio que reglamenta el sistema electoral colombiano. Posiblemente de esta situación deriva la producción del \# 4, Con Mira, la política es haciendo, referente al Partido Político Mira, institución religiosa independiente de los grupos tradicionales, que desarrolló una campaña con lista cerrada para el Senado de la República.

El 'lenguaje kinésico o lenguaje corporal', según Fernando Poyatos se representa en "los movimientos corporales y posiciones resultantes o alternantes de base psicomuscular, conscientes o inconscientes, somatogénicos o aprendidos, de percepción visual, auditiva, táctil o cinestésica (individual o conjuntamente), que, aislados o combinados con las estructuras verbales y paralingüísticas y con los demás sistemas somáticos y objetuales, poseen un valor comunicativo intencionado o no" (1994, pp. 185-186). 
En este sentido, aparecen los spots donde los candidatos acompañan los discursos orales con los movimientos de las manos: indicando direcciones y mostrando emociones, que se evidencian en estas piezas publicitarias: \# 2, La candidata aparece caminando frente a la cámara en los últimos 15 segundos, hablando y moviendo sus brazos; \# 7, De pie, mueve los brazos para hablar; \# 8, Sonrie, y mueve sus manos 'señalándose', como candidato;, y \# 9, Sonrie, aparece sentado y mueve su brazo derecho. También el \# 5, destreza para mover las fichas de ajedrez de la candidata por el Partido Cambio Radical, Nasly Cardoso, muestra solo movimientos corporales (rostro y brazos), transmitiendo inteligencia, capacidad y destreza para hacer la mejor jugada en la Cámara de Representantes por Boyacá.

Por otro lado, el 'lenguaje proxémico', línea semiótica que estudia la creación del espacio social y personal, y la forma como el hombre lo percibe (Morales, 1992), demuestra la distribución del espacio físico de los candidatos en las piezas publicitarias desde tres estilos. En el primero, los aspirantes aparecen en espacios abiertos o lugares representativos del departamento como la Plaza Bolivar de Tunja y/o campos agrícolas. En tal línea sobresalen los videos \# 1, Hay personas ubicadas en espacios abiertos de Tunja, hay fotos del candidato en reuniones grupales; \# 5, Campo abierto, centro histórico de Tunja, comparte un juego de ajedrez; \# 7, Sola rodeada de vegetación. En el segundo estilo, la distribución espacial se llevan a cabo en lugares cerrados: \# 2, Aparece sola en un espacio de fondo blanco; \# 8, Está solo, lo acompaña una animación o efectos navideño, y \# 9, Al parecer se encuentra en su residencia y aparece solo. Por su parte, en el tercer estilo algunos candidatos utilizan fotografías y los mismos videos para demostrar el apoyo de reconocidos actores políticos a nivel nacional y local como en \# 6, Comparte el espacio con Jorge Eduardo Londoño (candidato al Senado) y \# 10, Aparece en fotografia con Antanas Mockus y líderes del Partido Verde como Luis Eduardo Garzón.

Lo 'iridológico', se refiere al contacto visual frente a la cámara de video y las personas que rodean al candidato cuando es grabado. A partir de este concepto, se muestra el desarrollo de planos cerrados donde los aspirantes observan directamente a la cámara: \# 3, Se ubica directamente a la cámara de video; \# 6, Mira directamente a la cámara (fijación) y \# 8, Se enfoca directamente a la cámara; pose habitual que presentó la mayoría de competidores, evidenciando una técnica clásica de registro frente a la cámara de vídeo o fotografía. Contrario a este estilo aparece el spot (\# 5): No registra mirada ante la cámara, mirando el tablero de ajedrez. En esta pieza, la candidata aborda un plano abierto sin mirar a la cámara de vídeo que registra sus movimientos durante el movimiento de las fichas en el tablero (ver Figura 5).

Figura 5. Candidatos Rodrigo Rojas, Olegario Hernández y Nasly Cardoso
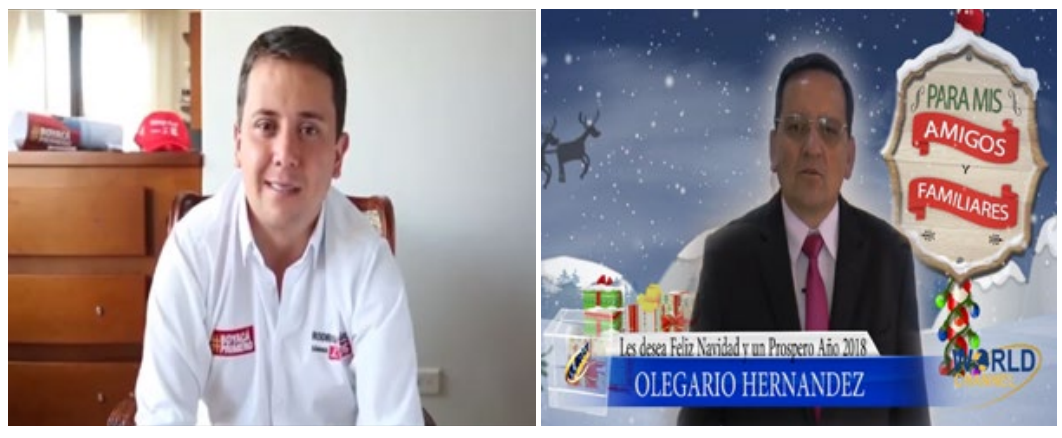

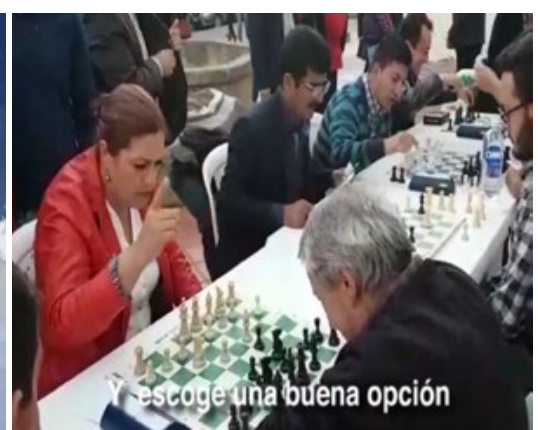

Siguiendo el 'lenguaje fisiológico', que reúne las características morfológicas de una persona como la edad, grupo étnico, forma corporal y demás condiciones anatómicas, se destaca la presencia activa de candidatos jóvenes entre los 27 a 38 años de géneros diversos. Los spots \#1, \#4, \#7 y \#9 reflejan dicha tendencia que marcó la participación de grupos poblacionales de jóvenes clasificados como millennials ${ }^{2}$ durante las elecciones de Congreso 2018 en el departamento de Boyacá. Los millennials

2. La Generación Millenial o Generación Y ha sido analizada ampliamente por diversos estudios, y aunque no hay un consenso general sobre el rango de edad de las personas que la componen, la mayoria la definen como la compuesta por los nacidos entre los años 1981 y 2000 . En ocasiones se amplian estos limites hasta los anos 1977 y 2004 (Ruiz, 2017, p. 350). Ademas, la revista Time, los define como The Me Me Me Ge Generation (La generacion del Yo Yo Yo), los Millennials suelen ser descriptos como perezosos, narcisistas, impacientes, egocentrícos y consentidos, pero al mismo deben liderarlo. 
no solamente se tomaron las elecciones legislativas en Boyacá: también resultaron elegidos al Congreso colombiano, como los Representantes a la Cámara Wilmer Leal Pérez (nacido en abril 9 de 1985), César Augusto Pachón Achury ( nacido el 21 de mayo de 1983), Rodrigo Arturo Rojas Lara (nacido en marzo 28 de 1985); los Senadores Ciro Alejandro Ramírez Cortés (nacido en octubre 31 de 1984) y Sandra Liliana Ortiz Nova (nacida en marzo 6 de 1977).

Antoni Gutiérrez (2020) señala en su artículo La generación Millennials y la nueva política, que dicha generación representa el punto de encuentro entre la vieja política y la nueva política desde,

la participación, pero para decidir. Guieren relacionarse, influir, decidir (e incluso enseñar) sobre los gobernantes. No se conformarán con ser meros receptores pasivos de decisiones, querrán participar de ellas. Se sienten preparados para afrontar retos: regeneración democrática. Ellos pueden y deben ser parte de los "nuevos actores", de la "nueva política". No aceptan ni privilegios, ni tutelas, ni dirigismos. ¿Quieren cambiar el mundo? Podrían, pero no lo han decidido, todavía. Aunque no les gusta el que tienen.

La constatación de que lo público (el interés general) ya no está garantizado -suficiente y exclusivamente- por lo político les es a los millennials más evidente cada día. Las limitaciones de la política formal (partidos e instituciones) les muestra descarnadamente su incapacidad para interpretar y comprender bien la realidad, seleccionar el capital humano y gestionar eficientemente los recursos públicos, representar a la ciudadanía generando entornos transparentes, confiables y permeables, y proponer soluciones sostenibles e innovadoras a los retos sociales con una acción ejecutiva y legislativa adecuada en tiempo y forma. En definitiva, la desconfianza de esta nueva generación crece por los límites de la política en su ejemplaridad y, también, en su eficiencia y eficacia. La corrupción es la puntilla (p. 163).

Atendiendo al dicho popular una imagen vale más que mil palabras, se manifiesta en la mayoría de candidatos el uso de prendas de color blanco y, en menor escala, los tonos representativos de los partidos o movimientos políticos que los avalaron. Es decir, el vestuario blanco fue uno de los elementos visuales más destacados en la producción de spots por parte de aspirantes boyacenses al Congreso en
2018. Esto probablemente pudo interpretarse de forma implícita como un mensaje a favor de los diálogos de paz con las FARC e iconográficamente significó el "bien" por alcanzar la paz en el país, lo "perfecto" para consolidar la paz, la "integridad"> por alcanzar la convivencia y paz, el "placer" por las emociones y sensaciones de una paz duradera, que demarca el estado de ánimo de los colombianos por alcanzar el éxito patriótico en la nación. Lo anterior es corroborado mediante los spots (\# 3) Camisa y fondo blanco en el afiche promocional de la campaña; (\# 6) Camisa de color blanco, utiliza un botón publicitario, logotipo del Partido Verde y (\# 7) Camisa de color rojo, el tono que representa el Partido Liberal que avaló su candidatura.

En tal sentido, la moda logra relacionarse con el concepto de imagen política como "elemento de suma importancia para el político, especialmente en época de campaña, donde la personalización se emplea incluso como estrategia electoral. En las campañas electorales personalizadas, el político se convierte en el contexto principal del mensaje. La personalización entonces, tiene como hilo argumentativo la figura y las cualidades del políticocandidato, lo que se conoce con el nombre de imagen (Orejuela, 2009, p. 62). En relación con la serie de estrategias captadoras de votos, se incluyen los aspectos externos del candidato, manifestados en la forma de apropiarse del mejor vestuario y la elección de colores que faciliten la transmisión de mensajes que proyecta su campaña.

Ruth Gómez de Travesedo y Marta Gil (2019) sostienen que históricamente el color ha sido empleado como estrategia de persuasión en distintos contextos: social, comercial, religioso, militar y político (Valdez, Huerta y Díaz, 2012). En el ámbito de la política, las formaciones se definen por unas siglas y por un color o colores que conforman su identidad y las diferencia ideológicamente. Es lo que se ha venido a denominar como "color político" o "color de partido". Este dota a la imagen del partido de una simbología determinada y normalmente acompaña a su propaganda electoral y a sus representantes y candidatos, especialmente en épocas de campaña (p. 102).

En consonancia con lo anterior, los spots \# 2, Vestida informalmente, con camisa blanca y chaleco publicitario color azul; \# 7, Camisa de color rojo, el tono que representa el Partido Liberal que avaló su candidatura, y \# 10, Camisa verde con el logo del Partido Verde, demuestran la relación directa 
con los colores ligados a los partidos políticos. Son un "elemento que aporta identidad a los partidos y los candidatos, hace más visible y atractiva su propaganda, moviliza emociones, logra un efecto en la conducta y el comportamiento de los votantes; tiene una connotación sociológica, ideológica e histórica" (Valdez, et al., 2012, pp. 36-37).

Por otra parte, para la categoría de valores no verbales' que establecen el tono de voz, volumen, entonación y el sonido agudo, existe una variedad de modulaciones en las voces de los candidatos: 'pausadas' en los spots \# 3 y \# 4; 'acentuación' en las piezas publicitarias \# 2 Patricia Guerrero, está con los jóvenes y \# 8 para la Cámara de Representantes, jlo nuevo!, Olegario Hernández Díaz; y 'voz en off' que registran el \# 1, \# 5 y \# 10. La voz en off, según Michel Chion se "caracteriza por su valor extradiegético: sonido off a aquel cuya fuente supuesta es, no solo ausente de la imagen, sino también no diegética, es decir, situada en un tiempo y un lugar ajenos a la situación directamente evocada: caso, muy extendido, de las voces de comentario o de narración, llamadas en inglés voice-over y, por supuesto, de la música orquestal".

Lo diegético, relativo a la diégesis ${ }^{3}$, es clasificado en cuatro categorías que expone Jesús García Jiménez (1993),

- Diegético-elíptico: la fuente del sonido que el espectador percibe no aparece ahora, pero ha aparecido con anterioridad en la imagen. En este caso el sonido es diegético y escuchado por alguno de los personajes de la historia.

- Diegético-citado: la fuente no ha aparecido con anterioridad en la imagen pero, asistido por el texto, resulta fácil para el espectador identificar el lugar exacto de donde procede. También es un sonido diegético y escuchado, al mismo tiempo que por el espectador, también por algún personaje. En consecuencia es un sonido diegético. De esta naturaleza son, por ejemplo, los ruidos (aullido de lobos, pasos, gemidos y demás efectos sonoros) que crean la atmósfera del cine de terror.

- Diegético-suspensivo: el espectador que escucha el sonido no dispone por el momento de elementos de juicio para identificar su origen, pero dispondrá de ellos después. El espectador percibe el sonido en algún momento a lo largo del relato junto con alguno de los personajes (sonido diegético).

- Extradiegético: la fuente del sonido ni ha aparecido con anterioridad, ni aparece posteriormente. En todo caso el espectador no dispone de elementos de juicio para poder identificar su lugar de procedencia. No es accesible para los personajes de ficción. Es el sonido en off más propiamente dicho. De esta naturaleza es la voz del narrador heterodiegético.

Las cuatro categorías de diegético son evidentes en los spots \#5, \#1 y \#10. En lo referente a la pieza \# 5, se articula lo diegético elíptico y citado, que parte de secuencias de imágenes con un fondo musical mostrando a la candidata Nasly Cardoso, quien juega una partida de ajedrez, enseguida 13 segundos después una voz en off canta "Nasly es la que viene ahí, tan sencilla y tan gentil [...]". La musicalización está acompañada de lo diegético citado al notarse los textos: Haz tu mejor movimiento - Y escoja una buena opción - Escoja la mejor ficha para avanzar.

En el spot \# 1 también prevalece lo diegéticoelíptico al notarse en el contenido historias y relatos orales de personajes de la calle que comentan su apoyo a Juan Fernando Jiménez: "Yo como deportista, apoyo a Juan Fernando Jiménez Rodríguez [...]" o "Los jóvenes también nos empoderamos de los escenarios políticos, y votamos por Juan Fernando Jiménez [...]”. Por su parte, el \# 10 maneja elementos de lo diegético suspensivo y extradiegético, que van desde "no identificar su origen, hasta las palabras de un personaje público invitando a votar por el candidato', y el 'sonido en off' que aparece en la pieza publicitaria: "Doctor Antanas Mockus, el departamento de Boyacá, también se une al Partido Verde, con el ingeniero Fabio Antonio Guerrero [...]".

\section{Matriz en las tipologias de Devlin}

Con base en las siete tipologías de spot que propone Patrick Devlin, se relacionan con la primera, "busto parlante o talking head ads', los spots \# 2 y \# 9 especialmente. Los candidatos Patricia Guerrero, del Partido Mira, y Rodrigo Rojas aparecen de frente a la cámara para exponer brevemente la propuesta legislativa: "este 11 de marzo, no te quedes sin votar, porque votar cuenta, Patricia Guerrero, está con los jóvenes" y "Rodrigo Rojas, trabajador, está en la política por vocación, fue elegido a los 26 años Diputado a la Asamblea del departamento [...]".

En la segunda tipología, 'cinéma verité,, están los spots \# 5 y \# 7, los cuales exhiben la vida

3. La diégesis, concepto que proviene de la lingüística, se define como "sucesión de las acciones que constituyen los hechos relatados en una narración o en una presentación (drama). Para Todorov equivale a historia, para Barthes, a relato, y para Rimmon, a significado" (Pérez, 2010, p. 76). 
de las candidatas Nasly Cardoso y Elsa Marlen Manrique desde el campo político: "Nasly es la viene ahí, la aspirante por el Partido Cambio Radical, se vende electoralmente como una estratega en el juego de ajedrez, y "Luis no tiene votos, Fernando no tiene votos, [...] todos tenemos un voto [...]", destaca la abanderada por el Partido Liberal, en cuanto al inconformismo de las comunidades por no tener un voto, para saber elegir y pensar en Boyacá.

En la categoría 'anuncios documentales' aparecen los logros expuestos por Cristóbal Rodríguez Hernández (spot \# 3), “acompañar a los alcaldes, en varios proyectos especiales como es la vivienda de interés social" y Rodrigo Rojas (spot \# 9), "elegido Diputado a los 26 años, en la Asamblea del departamento". Esta característica, merece ser analizada a través del concepto "vídeodependencia' de Giovanni Sartori (2012) que postula que los "políticos cada vez tienen menos relación con acontecimientos genuinos y cada vez se relacionan más con acontecimientos mediáticos” (p. 117). Es decir, se trata de una oportunidad que tienen los candidatos para visualizar de forma subjetiva, en treinta segundos, aspectos personales y referentes a los logros en la vida pública, frente a lo cual el mismo Sartori declara que "estos son agrandados o distorsionados por la cámara” (p. 118).

Dentro de la cuarta tipología, 'hombre de la calle', sobresalen las piezas publicitarias \# 1 y \# 2, las cuales recogen testimonios a favor de los candidatos Juan Fernando Jiménez: "El candidato a la Cámara Juan Fernando Jiménez, también apoya a los animalitos de la calle"; y la aspirante Patricia Guerrero: "Tu voto cuenta, Patricia Guerrero, está con los jóvenes" (Figura 6). La gente de la calle, suele representarse en aquellos grupos probablemente marginados del sistema socio-político, como los desempleados, comerciantes, ambientalistas, mujeres, jóvenes, etcétera, que terminan siendo gancho publicitario de los aspirantes para atraer votantes.

Figura 6. Candidatos Juan Fernando Jiménez y Patricia Guerrero

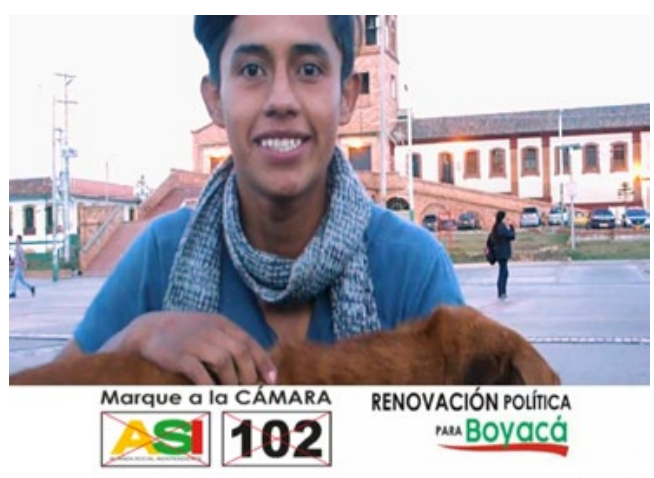

Entre tanto, la simulación realy cotidiana que destaca la tipología 'porción de vida' se evidencian en los spots \# 4 y \# 8. Las piezas comunicativas narran elementos reales como las grandes extensiones de campos agrícolas en Boyacá donde interviene el candidato al Senado de la República por el Partido Mira Sebastián Martínez. Por su parte, Olegario Hernández del Partido Conservador manifiesta un hecho cotidiano y coyuntural al desear en pleno proceso electoral, -diciembre de 2017-: "Una feliz navidad y un venturoso 2018".

En la sexta tipología hay 'testimonios' de personalidades públicas a nivel local y nacional. Es el caso del spot \# 6, donde Jorge Eduardo Londoño, quien fue Ministro de Justicia, Gobernador de Boyacá entre 2004 a 2007 y dirigente del

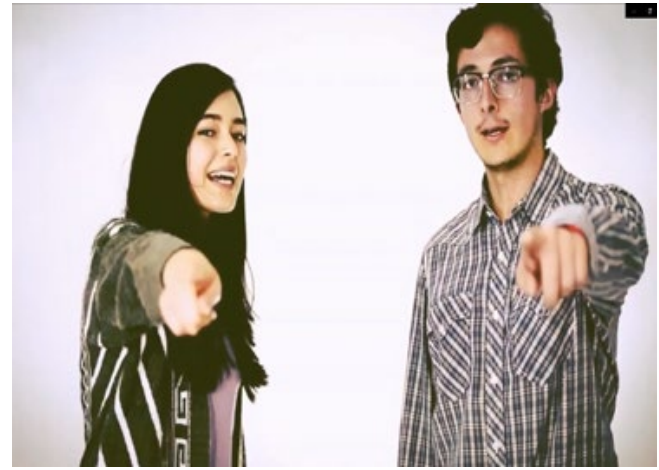

Partido Verde, invitó a votar por el aspirante de la circunscripción Cámara en el exterior Manuel José Alarcón. Asimismo, Antanas Mockus, excandidato a la presidencia y dos veces Alcalde de Bogotá, aparece en el spot \# 10 y le hace el guiño político a Fabio Antonio Guerrero, candidato a la Cámara de Representantes por Boyacá: "Bien [...] Fabio Antonio Guerrero, es una persona que tiene una trayectoria muy destacada [...]".

El guiño, aquel mensaje implícito que se ejecuta mediante un movimiento facial, o alocución de frases cargadas de símbolos a favor o en contra de alguna situación, suele emplearse con frecuencia en el escenario político, donde candidatos y hasta dirigentes lo utilizan para captar votos y desacreditar a sus contrincantes. Lo cual resulta notorio en la 
tipología 'testimonial': alli personajes de la vida pública brindan su espaldarazo de forma directa al candidato, como se muestra en la Tabla 2 que recoge

Tabla 2. Spots presidenciales 1994 y 2006 experiencias de spots exitosos de candidatos a la presidencia en Colombia:

\section{Elección presidencial 1994} Elección presidencial
2006

\section{Nombre del spot Samper, la mejor elección “todo bien, todo bien” El Partido de la U, es el "partido de Uribe"}

\begin{tabular}{ccc}
\hline Personaje & Carlos el 'Pibe' Valderrama (futbolista) & Álvaro Uribe Vélez (ex-presidente) \\
\hline Candidato & Ernesto Samper Pizano & Juan Manuel Santos Calderón \\
\hline Duración & 10 segundos & 31 segundos \\
\hline Muestra & & \\
\hline
\end{tabular}

Fuente: Elaboración propia con información tomada de spots de candidatos.

La última tipología de Devlin se ejemplifica con la pieza publicitaria \# 8 que 'presenta en sociedad' al candidato Olegario Hernández Díaz: "para la Cámara de Representantes, lo nuevo [...]". El competidor conservador aprovecha la época decembrina para venderse como el aspirante nuevo y a su vez buscó ganar adeptos y reconocimientos mediante los tradicionales mensajes de navidad, cargados de emociones, sentimientos, deseos, felicidades, unión familiar y éxitos venideros, frases que implícitamente incluyen una postura discursiva e ideológica a favor del Partido Conservador que avaló su aspiración a la Cámara de Representantes.

\section{Comentarios finales}

Las estrategias de campañas electorales durante las últimas dos décadas han tenido una transformación simultánea al surgimiento de la Internet, especialmente en la apropiación de las TIC que facilitan la interconexión de candidatos y partidos políticos con los nuevos canales comunicativos, lo que se traduce en oportunidades para la consecución de prácticas hacía la captación de votos que signifiquen una representación política en escaños.

Entre las prácticas captadoras de votos, aparece el spot político convertido en estrategia de seducción electoral durante el debate al Congreso colombiano 2018 en Boyacá. Esto determinó la circulación activa de piezas publicitarias como complemento en la exposición de propuestas legislativas que manejaron aspirantes la Cámara de Representantes y Senado de la República, quienes resumieron en 30 segundos las principales líneas de campaña. Los llamados a trabajar por Boyacá, viviendas para Boyacá, apoyos de jóvenes y mujeres, nuevos candidatos o nuevas ideas, y trabajar por el agro boyacense fueron las tendencias temáticas más comunes que narran las historias de los spots.

Las piezas publicitarias estuvieron acompañadas de personas de las calles (vendedores ambulantes, jóvenes, deportistas, mujeres cabeza de familia, etcétera), espacios emblemáticos de la capital boyacense, Tunja, y personas reconocidas en el ambiente local y nacional que intervinieron como modelos políticos, obviamente en favor de las candidaturas. Todo esto representó la apuesta en marcha de herramientas referentes a la profesionalización de campañas por parte de algunos candidatos al congreso por Boyacá, que asumieron el reto de apoyarse de asesores en mercadeo electoral.

Asimismo, el uso de medios digitales de última era evidencia los altos niveles de profesionalización decampañas. Ahora los candidatos 
boyacenses que intervienen en los diversos debates de elección popular encuentran en las -TIC un aliado estratégico para promocionar sus líneas discursivas desde la visualización de spots publicitarios. Lo cual es resultado de la Internet, espacio sin restricciones y gratuito que ofrece la oportunidad para desplegar vídeos en serie en la plataforma YouTube y la construcción de páginas web o blog que también inciden en la reproducción de los spots. Todo esto ha facilitado la participación equitativa de candidatos y partidos que presentan limitaciones presupuestales, lo que generaba cierto impedimento en la divulgación de sus productos audiovisuales en los medios de comunicación tradicionales o empresas informativas de importantes grupos económicos nacionales.

Lo anterior demuestra una transformación de la cultura política boyacense, caracterizada en la actualidad por el acceso a los medios digitales por parte de candidatos, partidos políticos y público en general, que han incorporado las TIC en los modos de vivir y ocuparse del seguimiento a las campañas políticas. La comunicación electoral clásica, en la que grandes empresas informativas controlaban los grandes flujos y sistemas comunicativos, ahora es compartida con las redes sociales y demás plataformas asociadas a los canales de última era. Ello también ha servido para multiplicar las audiencias políticas, que disfrutan de la información circulante y a su vez participan en el debate mediante la interacción informativa que termina siendo una herramienta necesaria para captar votos o reconocer e identificar a posibles públicos votantes.

Precisamente en lo pertinente a la multiplicación de las audiencias, se encuentran la participación activa de grupos de jóvenes en los spots \# 1 y \# 2, quienes invitan a votar por sus candidatos, algo que rompe con el estilo tradicional de promocionar las candidaturas en Boyacá, cuando se hacían directamente a través de la convocatoria de los mismos aspirantes o personalidades más destacadas dentro de la organización partidista. También la variedad de receptores, ha llevado a la producción de spots con características similares encontradas en los spots comerciales, que toman distancia de las piezas publicitarias politicas, las cuales logran ser identificadas por el desarrollo de mensajes alusivos a la ideología, partido, movimiento y propuestas gubernamentales o cuerpos colegiados.

Justamente, la ausencia de contenidos políticos en los spots de última era demuestra cómo los productores y los mismos candidatos han preferido omitir en varias piezas el nombre o simbología de los partidos y movimientos políticos que los avaló. Es decir, estas instituciones al parecer ya no representan ganchos estratégicos para afianzar los mensajes persuasivos de los aspirantes, por lo cual se intenta construir tímidamente spots con mensajes referentes a los partidos que terminan siendo casi desapercibidos o implícitos en el receptor, en razón probablemente al descredito, desconfianza y desencanto en la sociedad de tales organizaciones en las últimas tres décadas. No obstante, el Partido Verde sí manejó de forma explícita variada simbología que lo identifica como el color verde, la flor girasol (logotipo) y las invitaciones que hicieron personalidades reconocidas en la colectividad (Antanas Mockus y Lucho Garzón).

A grandes rasgos, en lo pertinente a los objetivos finales del trabajo, se observan distintas tipologías de spots que emplearon los candidatos por Boyacá al Congreso colombiano 2018, como las historias contadas, lenguaje iridológico, moda, busto parlante o talking head ads, anuncios documentales, hombre de la calle, entre otras que agruparon el conjunto de estrategias para persuadir o captar votos.

De igual forma, no existió alguna tendencia o característica específica de spot desarrollado por la mayoría de candidatos boyacenses. Se ejecutaron piezas con variedad de estilo y contenido pero la mayoría de aspirantes coinciden en utilizar locaciones asociadas en lugares representativos de Boyacá: Plaza Bolivar de Tunja, extensiones de campos agrícola, Puente de Boyacá, y elementos simbólicos al campesino de la región.

Por otra parte, los mensajes expuestos en los spots no tuvieron relación directa con la agenda mediática nacional, a excepción de los issues sobre la corrupción que sí fueron tratados de manera implícita, como lo muestran las piezas \# 1 , \# 7 y \# 8: "Yo voto por la renovación", "voto consciente" y "Olegario Hernández Díaz, lo nuevo a la Cámara”. Es necesario aclarar que en la época la agenda real del país consistía en el tratamiento informativo acerca de los diálogos de paz con las FARC, situación en Venezuela e inmigrantes y, en menor escala, aparecía la corrupción. Sin embargo, los candidatos al Congreso por Boyacá, le apostaron a tratar temas diferentes ligados a las necesidades sociales en el departamento y descredito de la clase política tradicional. 


\section{Referencias y fuentes consultadas}

Beccassino, Á. (2003). El precio del poder. Cómo se vende la imagen de un político. Bogotá: AGUILAR.

Carceller Cobos, C. (2013). La videopolítica en campaña: evolución del spot electoral en España entre 2004 y 2011. Vivat Academia, (124), pp. 1-20. https://doi.org/10.15178/va.2013.124.1-20

Castro Martínez, L. (2012). El marketing político en Estados Unidos: el caso Obama. Norteamérica, 7(1), pp. 209-222. Disponible en http:// www.scielo.org. $\mathrm{mx} / \mathrm{scielo}$.php? script=sci_arttext\&pid=S1870-35502012000100008\&lng=es\&tlng=es

Cebrián Herreros, M. (2012). Ecosistema mediático electoral Revista Mexicana de Comunicación, 25 (130), pp. 10-11.

Devlin, P. (1987). Political Persuasion in Presidential Campaigns. New Brunswick-USA: Transaction Books.

Fischer, D. (2005). Videopolítica: retórica del vacío. Información Pública, (2) , pp. 129-142.

García Jiménez, J. (1993). Narrativa audiovisual. Madrid: Cátedra.

Gómez de Travesedo, R. y Gil Ramírez, M. (2019). Vestir la política: la indumentaria como estrategia en comunicación electoral. Revista Internacional de Relaciones Públicas, IX (18), pp. 95-118. https://doi.org/10.5783/RIRP-18-2019-06-95-118

Gutiérrez-Rubí, A. (2020). La generación Millennials y la nueva política. Revista Estudios de JuventudJóvenes y generación 2020. (108) pp. 161-171.

Ibinarriaga, J.A. y Hasbun Roberto (Trad) (2012). El arte de la guerra electoral. México: Grijalbo.

Juárez Gámiz, J. (2010). El papel de la publicidad política en la nueva ley electoral: una mirada crítica. Sociológica, 25 (72), pp. 43-70.

Lozano García, M. (2014). Spots electorales, estrategia persuasiva en los comicios de Congreso en Colombia-2014: experiencias de las candidaturas en Boyacá. Revista Latinoamericana de ciencias de la comunicación ALAIC, 11 (21) pp. 160-173. https://revista.pubalaic.org/index.php/alaic/ article/view/546

Martínez Castillo, G. (2010). Campañas presidenciales históricas de Norteamérica: (de 1952 a 2008). La americanización de las campañas electorales. [presentación diapositivas] Slideshare. https://www.slideshare.net/gm5/1952-campaas-histricas-norteamericanas

Martí Perelló, S. y Vallhonrat Bodas, S. (1999). Lo verbal y lo no verbal en el mensaje Publicitario televisivo. Contexto (XVII-XVIII), pp. 223-241.

Morales M., Manuel. (1992). La proxémica urbana de Medellín. Medellín: Concejo de Medellín

Orejuela, S. (2009). Personalización política: la imagen del político como estrategia electoral. Revista de Comunicación, (8), pp. 60-83.

Peña Jiménez, P. (2011). El video electoral como estrategia persuasiva en la campaña 2011. España: Universidad Rey Juan Carlos; Congreso ALICE, 2011.

Pérez Suárez, J. M. (2010). Diccionario de Comunicaciones. Medellín: Sello editorial Universidad de Medellín.

Peytibi, X. (2016). Videopolítica: de la televisión de Rosser Reeves a la generación Youtube. En

R. Sánchez (Ed.), Comunicación política. Nuevas dinámicas y ciudadanía permanente (pp. 149-175). Madrid: Tecnos.

Poyatos, F. (1994). La comunicación no verbal I y II. Madrid: Istmo.

Ruiz Cartagena, J. J. (2017). Millennials y redes sociales: estrategias para una comunicación de marca efectiva. Miguel Hernández Communication Journal, (8), pp. 347-367. https://doi.org/10.21134/ mhcj.v0i8.196

Salmon, C. (2008). Storytelling. La máquina de fabricar historias y formatear las mentes. Barcelona: Atalaya.

Sartori, G. (2012). Homo videns. La sociedad teledirigida. España: Taurus, p. 205. https://doi. org/10.5354/0717-9162.2003.10669

Suárez Tello, E.M. (2017). Redes sociales y electores en Internet: hacia las campañas políticas de 2018 . Revista Mexicana de Comunicación, 1 (141).

Telles, H. y Lavareda, A. (2015). Voto e Estratégias de Comunicação Política na América Latina. Editora: Appris, Curitiba

Valdez, A., Huerta, D. y Díaz, S. (2012). El color como parte de la estrategia de persuasión política: El caso de los XVI Juegos Panamericanos, Guadalajara 2011. Contratexto, (020), pp. 29-51. https://doi.org/10.26439/contratexto2012.n020.171 


\section{Anexos}

Spot 1. Yo voto por la renovación

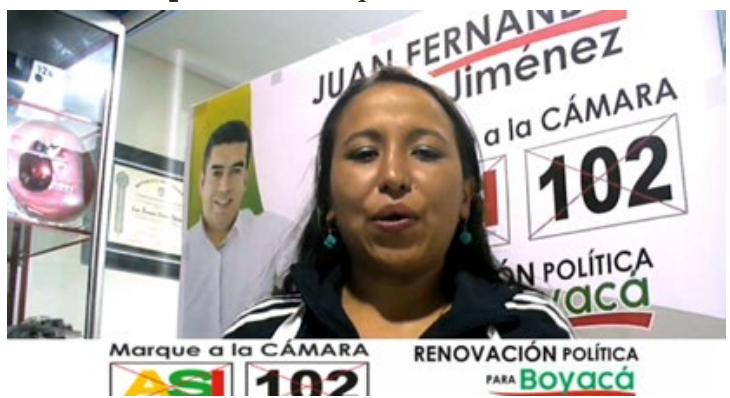

Spot 3. Boyacá razón de lucha

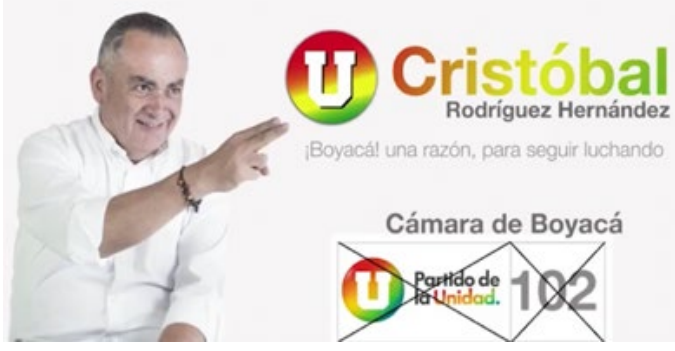

Spot 5. Boyacá razón de lucha

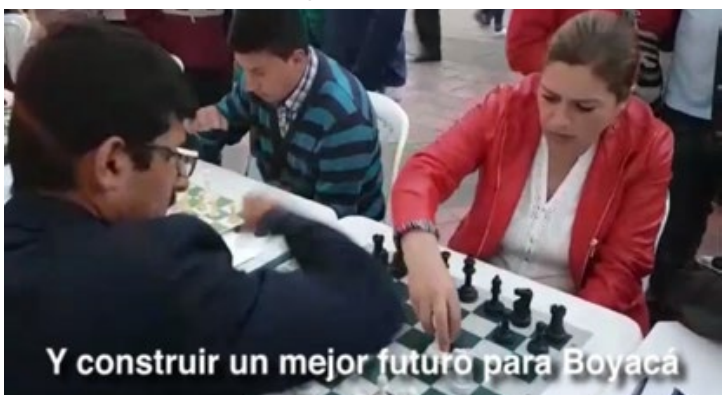

Spot 7. Voto consciente

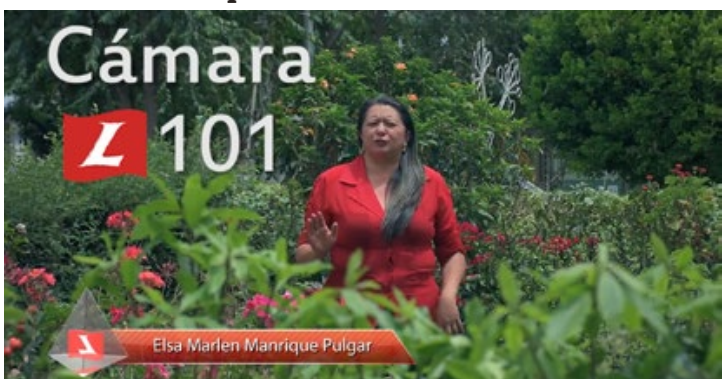

Spot 9. 106 segundos con Rojas

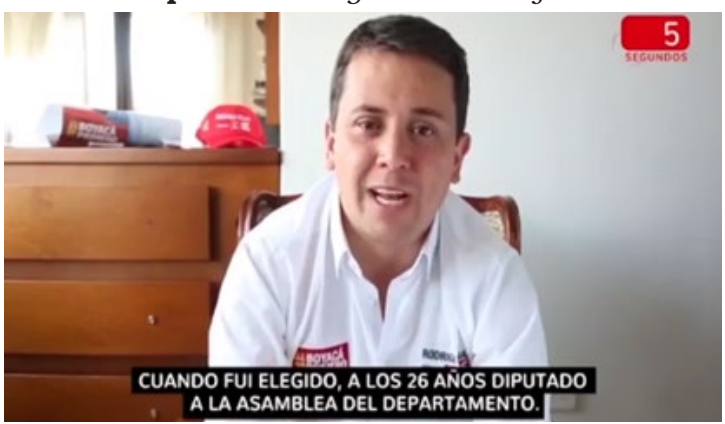

Spot 2. Por qué vas a votar

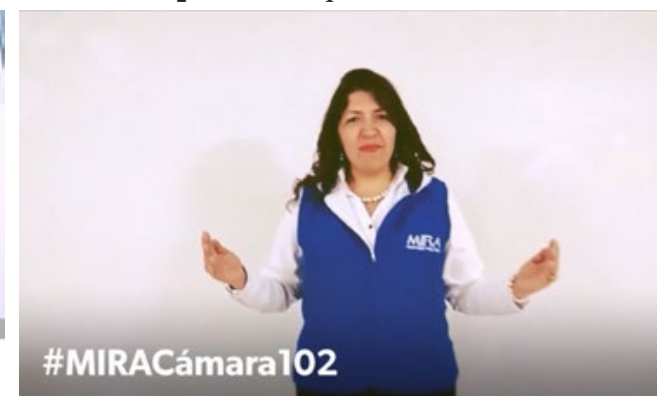

Spot 4. Cómo votar al Senado

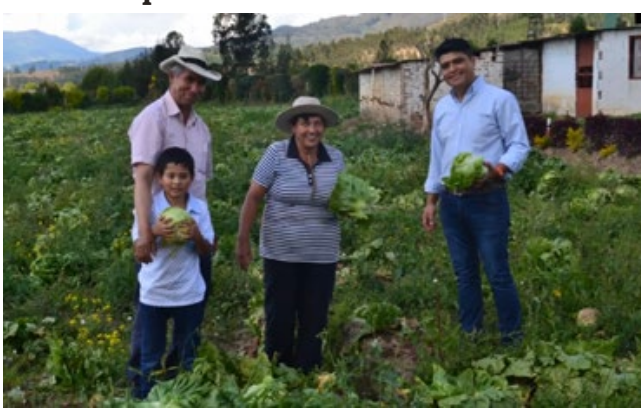

Spot 6. Cómo votar al Senado

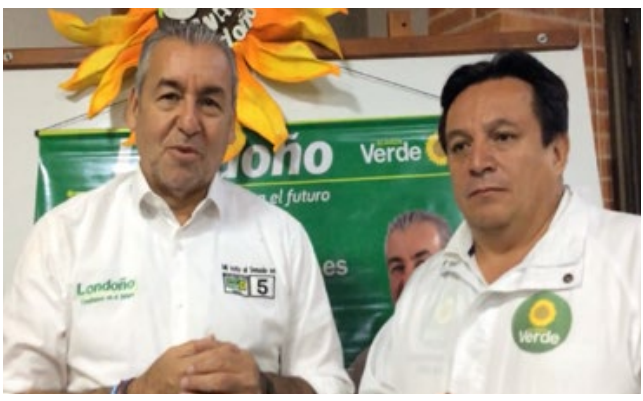

Spot 8. Saludo navideño Hernández

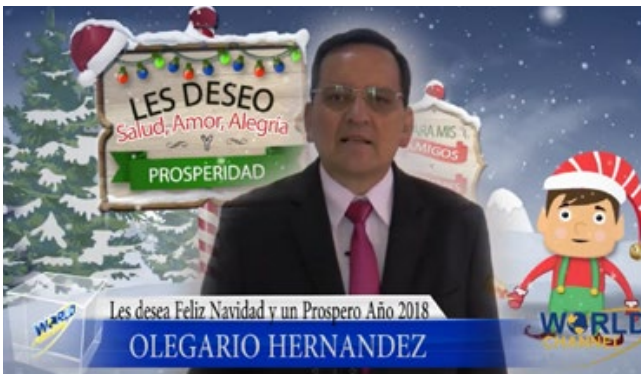

Spot 10. Apoyo de Antanas Mockus

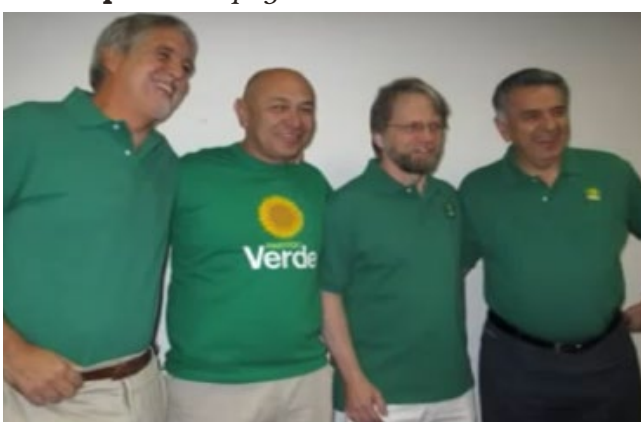

